\title{
CARTILAGE CONSTRUCTS ENGINEERED FROM CHONDROCYTES OVEREXPRESSING IGF-I IMPROVE THE REPAIR OF OSTEOCHONDRAL DEFECTS IN A RABBIT MODEL
}

\author{
Henning Madry ${ }^{1,2, *}$, Gunter Kaul ${ }^{1}$, David Zurakowski ${ }^{3}$, Gordana Vunjak-Novakovic ${ }^{4}$ and Magali Cucchiarini ${ }^{1}$ \\ ${ }^{1}$ Centre of Experimental Orthopaedics, Saarland University, Homburg, Germany \\ ${ }^{2}$ Department of Orthopaedic Surgery, Saarland University, Homburg, Germany \\ ${ }^{3}$ Departments of Anaesthesia and Surgery, Children's Hospital, Harvard Medical School, Boston, MA, USA \\ ${ }^{4}$ Department of Biomedical Engineering, Columbia University, New York, NY, USA
}

\begin{abstract}
Tissue engineering combined with gene therapy is a promising approach for promoting articular cartilage repair. Here, we tested the hypothesis that engineered cartilage with chondrocytes overexpressing a human insulin-like growth factor I (IGF-I) gene can enhance the repair of osteochondral defects, in a manner dependent on the duration of cultivation. Genetically modified chondrocytes were cultured on biodegradable polyglycolic acid scaffolds in dynamic flow rotating bioreactors for either 10 or $28 \mathrm{~d}$. The resulting cartilaginous constructs were implanted into osteochondral defects in rabbit knee joints. After 28 weeks of in vivo implantation, immunoreactivity to $\beta$-gal was detectable in the repair tissue of defects that received lac $Z$ constructs. Engineered cartilaginous constructs based on IGF-I-overexpressing chondrocytes markedly improved osteochondral repair compared with control (lacZ) constructs. Moreover, IGF-I constructs cultivated for $28 \mathrm{~d}$ in vitro significantly promoted osteochondral repair vis-à-vis similar constructs cultivated for $10 \mathrm{~d}$, leading to significantly decreased osteoarthritic changes in the cartilage adjacent to the defects. Hence, the combination of spatially defined overexpression of human IGF-I within a tissue-engineered construct and prolonged bioreactor cultivation resulted in most enhanced articular cartilage repair and reduction of osteoarthritic changes in the cartilage adjacent to the defect. Such genetically enhanced tissue engineering provides a versatile tool to evaluate potential therapeutic genes in vivo and to improve our comprehension of the development of the repair tissue within articular cartilage defects. Insights gained with additional exploration using this model may lead to more effective treatment options for acute cartilage defects.
\end{abstract}

Keywords: Tissue engineering; gene therapy; articular chondrocytes; bioreactor; insulin-like growth factor I; transplantation; scaffold; osteochondral defects; cartilage repair; osteoarthritis.

*Address for correspondence:

Henning Madry

Centre of Experimental Orthopaedics

Medical Faculty

Building 37

Saarland University

D-66421 Homburg, Germany

Telephone Number: +49-6841-1624515

FAX Number: +49-6841-1624988

E-mail: henning.madry@uks.eu

\section{Introduction}

Articular cartilage has only limited ability to repair following an acute osteochondral injury (Hunziker, 2009). Mesenchymal cells from the bone marrow repopulate the defect and form a fibrocartilaginous tissue of lesser quality than the original cartilage (Shapiro et al., 1993). Although different reconstructive surgical interventions are available, none of them allows for complete and durable articular cartilage regeneration (Hunziker, 2002; Redman et al., 2005; Safran and Seiber, 2010; van Osch et al., 2009). It is because of this inability to restore the original cartilage structure that there is great clinical interest in developing novel strategies for cartilage repair (Dell'accio and Vincent, 2010).

Tissue engineering (Langer and Vacanti, 1993) and gene therapy (Cucchiarini and Madry, 2005; Evans et al., 2000) are two promising alternate approaches to cartilage regeneration. Functional substitutes for native cartilage can be generated from articular chondrocytes (Wolf et al., 2008) and transplanted into cartilage defects in vivo, to enhance cartilage repair compared to defects left empty or treated with cell-free scaffolds (Schaefer et al., 2002). Gene delivery of regulatory signals to the chondrocytes within these constructs could further enhance chondrogenesis (Saltzman, 1999).

Insulin-like growth factor I (IGF-I) is a particularly compelling candidate for gene transfer to chondrocytes (Mauck et al., 2003; Nixon et al., 2000; Nixon et al., 2005; Pei et al., 2002), as it simultaneously increases chondrocyte proliferation (Trippel et al., 1989) and the synthesis of type-II collagen (van der Kraan et al., 2002) and proteoglycans (Luyten et al., 1988; Morales and Hascall, 1989). Isolated IGF-I overexpressing articular chondrocytes led to enhanced cartilage repair in vivo when implanted in a lapine osteochondral defect model (Madry et al., 2005). In vitro, tissue engineering is improved when such chondrocytes overexpressing IGF-I are used to engineer cartilage, as shown by the enhanced morphological, biochemical and biomechanical parameters of these constructs (Madry et al., 2002). When applied to the problem of cartilage repair, this approach would allow immediate filling of the defect with a structure that actively supports chondrogenesis (Evans, 2011; Ivkovic et al., 2011); in contrast to the less targetable intra-articular delivery of a therapeutic gene vector (Madry et al., 2011a). It remains unknown, however, whether such spatially defined overexpression of an IGF-I sequence in tissue-engineered cartilaginous constructs enhances the repair of osteochondral defects in vivo. 
Here, we utilised enhanced chondrogenesis within tissue-engineered cartilage via genetically modified chondrocytes in vitro to repair an acute cartilage defect model in vivo. We specifically tested the hypothesis that tissue-engineered cartilaginous constructs created from chondrocytes overexpressing a human IGF-I cDNA can enhance the repair of osteochondral defects in vivo. We also tested the hypothesis that a longer cultivation period of the constructs prior to implantation ( $28 \mathrm{~d}$ in vitro) results in improved repair in vivo, vis-à-vis a shorter cultivation period (cultured for $10 \mathrm{~d}$ in vitro). Moreover, since osteoarthritis (Goldring and Goldring, 2010) is a clinically significant potential long-term consequence of a focal cartilage defect (Schinhan et al., 2012), osteoarthritic changes in the adjacent articular cartilage were assessed.

\section{Materials and Methods}

\section{Experimental design}

Cartilaginous constructs were engineered using allogeneic lapine articular chondrocytes transfected with expression plasmid vectors carrying either the Escherichia coli ( $E$. coli) B-galactosidase (lacZ) gene (referred to as lacZ constructs) or a human IGF-I cDNA (IGF-I constructs) (Fig. 1). Previously, we have documented the histological, biochemical, and biomechanical in vitro properties of these constructs (including transgene expression), and demonstrated an enhancement of structural and functional features of engineered cartilage in vitro by spatially defined overexpression of human IGF-I (Madry et al., 2002).

One day after transfection, modified chondrocytes were dynamically seeded onto polyglycolic acid scaffolds that allow for sustained transgene expression and controlled chondrogenesis in vitro and in vivo (Freed et al., 1994; Freed et al., 1998; Madry et al., 2002; Schaefer et al., 2002). Two days after seeding, both types of constructs were transferred into rotating bioreactors and cultivated for either 10 or $28 \mathrm{~d}$. The constructs were then removed from the bioreactors at these two time points and transplanted into osteochondral defects in the patellar groove of rabbits.

Four experimental groups were formed: (1) lacZ and (2) IGF-I constructs cultivated for $10 \mathrm{~d}$ in vitro and implanted in the left and right knees ( $n=7$ animals); (3) lac $Z$ and (4) IGF-I constructs cultivated for $28 \mathrm{~d}$ in vitro and implanted in the left and right knees ( $n=7$ animals). Twenty-eight weeks post implantation, animals were euthanised and the distal femurs were analysed.

\section{Materials}

Reagents were obtained from Invitrogen/GIBCO (Karlsruhe, Germany) unless otherwise indicated. The polyglycolic acid scaffold was from Cellon (Strassen, Luxembourg), collagenase type I (activity: $232 \mathrm{U} / \mathrm{mg}$ ) from Biochrom (Berlin, Germany), and bovine testicular hyaluronidase from Sigma (Munich, Germany). Plastic ware was from Falcon (Becton Dickinson, Pont de Claix, France).

Table 1. Inverse semi-quantitative score.

\begin{tabular}{|l|l|c|}
\hline Category & Evaluation & Points \\
\hline Contracture & No & 0 \\
\hline & Yes & 1 \\
\hline Effusion & No & 0 \\
\hline & Yes & 1 \\
\hline Intra-articular adhesions & No & 0 \\
\hline & Yes & 1 \\
\hline Synovialitis & No & 0 \\
\hline & Yes & 1 \\
\hline Osteophytes & No & 0 \\
\hline & Yes & 1 \\
\hline Colour of the defect & White & 0 \\
\hline & Translucent & 1 \\
\hline & Dark & 2 \\
\hline Surface of the defect & Smooth & 0 \\
\hline & Fibrillated & 1 \\
\hline & Total degeneration & 2 \\
\hline Integration with adjacent cartilage & Complete integration & 0 \\
\hline & Demarcating border & 1 \\
\hline Filling of the defect & Protruding & 1 \\
\hline & In level with adjacent cartilage & 0 \\
\hline & $50 \%$ repair of defect depth & 1 \\
\hline & $0 \%$ repair of defect depth & 2 \\
\hline Maximal points & & $\mathbf{1 2}$ \\
\hline
\end{tabular}

Values of all individual categories were added. A macroscopic normal joint and defect appearance would receive 0 points. 
Cell culture, transfection, and seeding onto scaffolds All animal procedures were approved by the local governmental animal care committee and were conducted in accordance with the German legislation on protection of animals and the NIH Guidelines for the Care and Use of Laboratory Animals (NIH Publication \#85-23 Rev. 1985). Animals were housed one per cage in air-conditioned rooms with constant temperature and a regular light/dark scheme. They had free access to tap water and were fed a standard diet.

Articular chondrocytes were isolated from articular cartilage obtained from the knee and hip joints of two male skeletally immature Chinchilla bastard rabbits to allow for a high rate of chondrogenesis (Wei and Messner, 1999) (mean weight: $2.1 \pm 0.5 \mathrm{~kg}$; Charles River, Sulzfeld, Germany) as previously described (Madry et al., 2003) and expanded in DMEM with $50 \mu \mathrm{g} / \mathrm{mL}$ ascorbic acid, $100 \mathrm{U} / \mathrm{mL}$ penicillin $\mathrm{G}$ and $100 \mu \mathrm{L} / \mathrm{mL}$ streptomycin (basal medium). The cell number was determined by haemocytometry. Viability was determined by trypan blue exclusion and always exceeded $90 \%$.

Chondrocytes were transfected using the nonliposomal lipid formulation FuGENE 6 (Roche, Mannheim, Germany) with endotoxin-free expression plasmid vectors carrying either lacZ (pCMVlacZ) (Madry and Trippel, 2000) or a human IGF-I cDNA (pCMVhIGF-I) (Madry et al., 2002; Madry et al., 2001) under the control of the human cytomegalovirus (CMV) immediate-early promoter/enhancer as previously described (Madry et al., 2003) using chondrocytes at passage 2 on days 10-14 after cell isolation, seeded at a density of $1.2 \times 10^{6}$ cells/flask in basal medium containing $10 \%$ foetal bovine serum (growth medium) in T-75 flasks. Aliquots of chondrocytes used for seeding in the scaffolds were also processed for X-Gal staining.

One day after transfection, chondrocytes were dissociated from the culture plates, re-suspended in growth medium and dynamically seeded onto polyglycolic acid (PGA) scaffolds (3.5 mm diameter x $1.5 \mathrm{~mm}$ fibrous discs, $2.5 \times 10^{6}$ cells/scaffold) as previously described (Madry et al., 2002). Aliquots $(10 \mu \mathrm{L})$ of the seeding medium were removed after 1, 24, 36 and $48 \mathrm{~h}$ and cell numbers were determined to estimate the number of cells per scaffold and time point. Two days after initiating the seeding, cell-polymer constructs were transferred into rotating bioreactors containing basal medium (RCCV-110, Cellon, Strassen, Luxembourg) (Freed et al., 1998; Madry et al., 2002). The vessel rotation rate was adjusted to allow for a free suspension of each construct in the rotational flow. The constructs were assessed for wet weight at the time of transfer to the bioreactor and implantation. The medium was replaced every $5 \mathrm{~d}(50 \%)$. Gas exchange was continuous.

\section{Implantation of genetically modified cartilaginous constructs}

The implantation of the lacZ or IGF-I constructs was performed either after 10 or $28 \mathrm{~d}$ of bioreactor cultivation in vitro (Fig. 1). Male Chinchilla bastard rabbits ( $n=14$; mean weight: $2.8 \pm 0.3 \mathrm{~kg}$; Charles River) were anaesthetised by intramuscular injection of Ketavet $(0.75 \mathrm{mg} / \mathrm{kg}$ of body weight; Pharmacia \& Upjohn, Erlangen, Germany) and Rompun $(0.2 \mathrm{~mL} / \mathrm{kg}$ of body weight; Bayer, Leverkusen, Germany). The knee joint was entered through a medial parapatellar approach, the patella was dislocated laterally and the knee was flexed to $90^{\circ}$. A cylindrical osteochondral cartilage defect of standardised depth $(4.0 \mathrm{~mm})$ was created in each patellar groove $(n=28$ defects) with a manual cannulated burr (3.2 mm in diameter; Synthes, Umkirch, Germany). Each defect was washed with saline and blotted dry. Engineered cartilaginous constructs were press-fit into the defects. The right and left knees alternately received lacZ or IGF-I constructs. Constructs from one single preparation were employed in all defects. The patella was reduced, the knee was put through a range of motion to assure the stability of the constructs and the incisions were closed in layers. Immediately postoperatively, the animals were allowed unrestricted activity and full weight bearing without any immobilisation, then to climb and jump 6 weeks after the implantation.

\section{Detection of transgene expression}

Detection of $\beta$-galactosidase activity in transfected chondrocytes was performed by X-Gal staining using a standard protocol (Madry et al., 2003) and in tissue sections by incubation with a 1:100 dilution of a mouse anti-ß-gal antibody (GAL-13) (Sigma). The production of IGF-I was determined from the cell culture supernatants

Table 2. Effects of tissue-engineered constructs based on chondrocytes overexpressing lacZ and IGF-I on the on the histological grading of the synovial membrane after 28 weeks in vivo.

\begin{tabular}{|c|c|c|c|c|}
\hline \multirow{2}{*}{ Category } & \multicolumn{2}{|c|}{$\mathbf{1 0}$ days } & \multicolumn{2}{c|}{ 28 days } \\
\cline { 2 - 5 } & $\begin{array}{c}\text { lac } \boldsymbol{Z} \\
\text { constructs }\end{array}$ & $\begin{array}{c}\text { IGF-I } \\
\text { constructs }\end{array}$ & $\begin{array}{c}\text { lacZ } \\
\text { constructs }\end{array}$ & $\begin{array}{c}\text { IGF-I } \\
\text { constructs }\end{array}$ \\
\hline Villus thickening & $1.3(0.5)$ & $1.0(0.6)$ & $1.2(0.4)$ & $1.0(0)$ \\
\hline Villus architecture & $1.0(0.9)$ & $0.5(0.5)$ & $0.8(0.4)$ & $0.3(0.5)$ \\
\hline Inflammatory cell infiltrate & $0.8(1.0)$ & $0.2(0.4)$ & $0.3(0.5)$ & $0(0)$ \\
\hline Average total score & $\mathbf{3 . 2}$ & $\mathbf{1 . 7}$ & $\mathbf{2 . 3}$ & $\mathbf{1 . 3}$ \\
\hline SD & 2.3 & 1.4 & 1.4 & 0.5 \\
\hline
\end{tabular}

Each category and total score is calculated as the average score performed by two blinded evaluators. Data are expressed as mean \pm S.D. 


$\begin{array}{ccccc}\text { Nonviral } & \text { Seeding in } & \text { Bioreactor } & \text { Transplantation in } & \text { Evaluation } \\ \text { gene transfer } & \begin{array}{c}\text { polymeric } \\ \text { scaffolds }\end{array} & \text { cultivation } & \text { in vitro } & \text { defects } \\ & & & \text { in vivo }\end{array}$

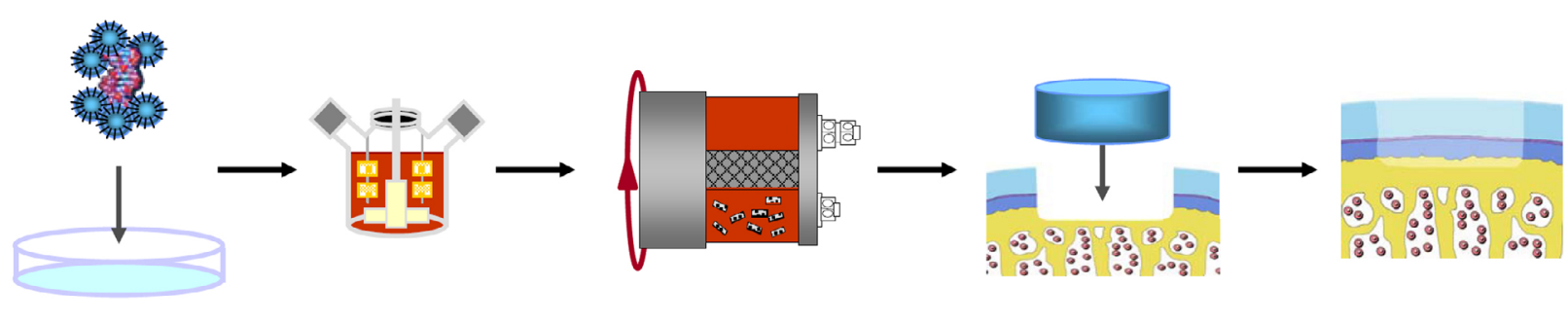

lacZ / IGF-I

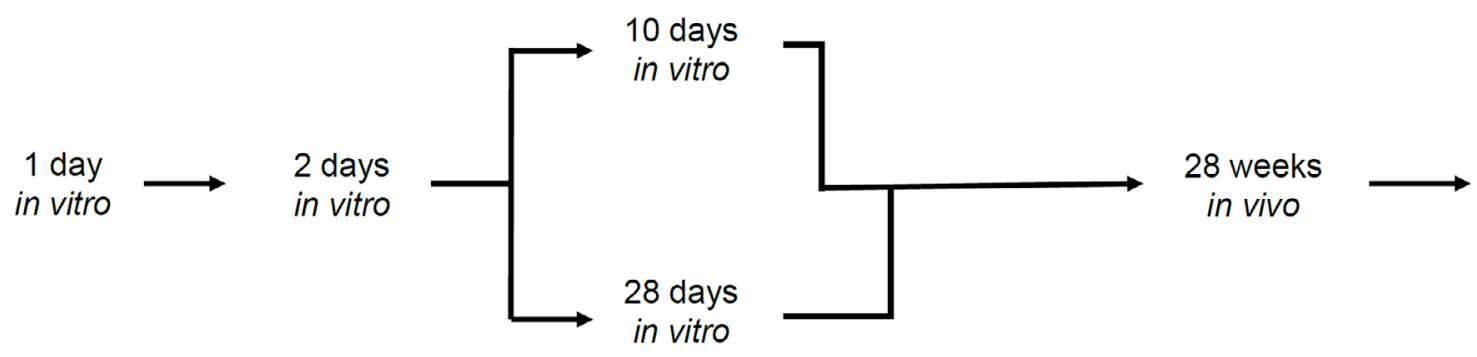

Fig. 1. Experimental design. Primary rabbit chondrocytes were isolated, placed in monolayer culture and transfected with wither lacZ or IGF-I expression plasmid vectors using FuGENE 6. At day 1 post transfection, the chondrocytes were released and dynamically seeded into polymeric scaffolds in spinner flasks. At day 3 post transfection (day 2 post seeding), the resulting lacZ or IGF-I constructs were transferred into rotating bioreactors and cultivated for either 10 or $28 \mathrm{~d}$ in vitro. At these two time points, the lac $Z$ and IGF-I constructs were removed from the bioreactors and transplanted into osteochondral defects in the patellar groove of rabbits. Twenty-eight weeks post implantation, animals were euthanised and the distal femora were retrieved and analysed.

of transfected chondrocytes cultivated in monolayer and of engineered cartilaginous constructs. To determine IGF-I secretion from the constructs, 2 samples from each group were removed from the bioreactors at days $3,5,10,13$, 18, 24 and 31 after transfection and individually cultivated in 24 -well plates in $500 \mu \mathrm{L}$ basal medium. After $12 \mathrm{~h}$, the conditioned medium was collected and the constructs were returned to the bioreactors.

To monitor the IGF-I amount in the synovial fluid, a lavage (1 mL phosphate-buffered saline, PBS) of the knees was performed at the time of sacrifice. The samples were analysed after extraction of binding proteins using an IGF-I ELISA (R\&D Systems, Wiesbaden, Germany) with a detection limit of $26 \mathrm{pg} / \mathrm{mL}$. To examine the expression of IGF-I in the defects, immunohistochemical analysis of tissue sections was performed using a 1:25 dilution of a polyclonal goat anti-IGF-I antibody (AF-291-NA) (R\&D Systems). Immunoreactivity to IGF-I was compared to articular chondrocytes of a normal lapine osteochondral unit.

\section{Macroscopic evaluation of the specimen}

Two rabbits were removed from the protocol because of death caused by gastrointestinal infections unrelated to the surgical treatment at weeks 2 and 24 post operation. At 28 weeks post-operation, the animals were euthanised. The knee joints were exposed and macroscopically examined using an inverse semi-quantitative score (Table 1) (Orth et al., 2011). Values of all individual categories were added. A macroscopic normal joint and defect appearance would receive 0 points.

\section{Histological and immunohistochemical analyses}

The distal femurs were retrieved, fixed in $4 \%$ phosphatebuffered formalin, trimmed to $2.0 \times 1.5 \times 1.0 \mathrm{~cm}$, and decalcified. Following decalcification, distal femurs were trimmed close to the proximal border of that interface and embedded, to assure that the subsequent cutting was moving from the periphery of the repair tissue in the defect towards the centre. Paraffin-embedded frontal sections $(5 \mu \mathrm{m})$ of the distal femora starting from the proximal border of the defect were taken at $200 \mu \mathrm{m}$ intervals. Peripheral sections as identified by image analysis of their width (less than $2.0 \mathrm{~mm}$ ) were excluded. All sections were taken within approximately $1.2 \mathrm{~mm}$ from the centre of the defects $(n=5-10$ per defect).

Sections were stained with Safranin O and haematoxylin and eosin (HE) (Kiernan, 1999). For type-I and type-II collagen immunostaining, deparaffinised sections were submerged for $30 \mathrm{~min}$ in $0.3 \%$ hydrogen peroxide. After washing with PBS, sections were incubated for $30 \mathrm{~min}$ in $0.1 \%$ trypsin, washed with PBS and blocked with $3 \%$ bovine serum albumin in PBS (blocking buffer) for $30 \mathrm{~min}$. The sections then were incubated with a 1:50 dilution of a monoclonal mouse anti-human type-I collagen $\mathrm{IgG}$ or a 1:10 dilution of a monoclonal mouse anti-human 
type-II collagen IgG (Medicorp AF-5610 and AF-5710, respectively, Montréal, Canada) in blocking buffer for $24 \mathrm{~h}$ at $4{ }^{\circ} \mathrm{C}$, washed and exposed to a 1:100 dilution of a biotinylated anti-mouse antibody (Vector Laboratories, Burlingame, CA, USA) for $1 \mathrm{~h}$ at room temperature. The sections were washed, incubated for $30 \mathrm{~min}$ with avidinbiotin-peroxidase reagent (Vectastain Elite ABC kit; Vector Laboratories), washed and exposed to diaminobenzidine (Vector Laboratories). Control tissues for the primary antibodies included lapine skin and lapine articular cartilage. To examine the potential infiltration of immune cells in the defects, immunohistochemical analysis of tissue sections was performed using a mouse monoclonal antiCD11b antibody (Ly-40; Acris, Hiddenhausen, Germany) to detect activated macrophages, a mouse monoclonal anti-CD3 antibody (PC3/188A; DakoCytomation, Hamburg, Germany) to detect CD3 (T-lymphocytes) and a mouse monoclonal anti-HLA-DR $\alpha$ antibody (TAL.1B5; DakoCytomation) to detect class II MHC antigens. These antibodies have been shown to cross-react with a large panel of species, including the rabbit. To control for all secondary immunoglobulins, sections were processed as described above with omission of the primary antibody.

The synovial membrane adjacent to the articular cartilage was evaluated on HE-stained sections using a previously published scoring system (Fortier et al., 2002; Nixon et al., 1999) (Table 2). Visualisation of the collagens within the repair tissue was performed on HE-stained histological sections using polarised light microscopy (BX-45, Olympus, Hamburg, Germany).

Immunoreactivity to type-I collagen in the repair tissue was compared to articular cartilage (negative control), and to that of the subchondral bone (positive control), both of a normal lapine osteochondral unit. Immunoreactivity to type-II collagen in the repair tissue was compared to articular cartilage (positive control), and to that of the subchondral bone (negative control), both of a normal lapine osteochondral unit. A 0-4 point score was given to each knee: 0 , no immunoreactivity; 1 , significantly weaker immunoreactivity; 2 , moderately weaker immunoreactivity; 3 , similar immunoreactivity; 4, stronger immunoreactivity (Kaul et al., 2006; Madry et al., 2005).

The adjacent articular cartilage was evaluated for early osteoarthritic changes based on the part of the histological score described by Solchaga et al. (2000), which determines osteoarthritic changes using Safranin O-fast green-stained sections. A $2 \mathrm{~mm}$ area of articular cartilage adjacent to both defect edges (excluding the area of integration that is independently scored in the score described by Sellers) was evaluated. Score points were given as follows: normal cellularity, no clusters, and normal staining: 0 points; normal cellularity, mild clusters, and moderate staining: 1 point; mild or moderate hypocellularity, and slight staining: 2 points; severe hypocellularity, and poor or no staining: 3 points.

For a quantitative assessment of the repair tissue, Safranin O-fast green stained sections ( $n=9-10$ per defect) were analysed using the complex cartilage repair score described by Sellers et al. (Orth et al., 2012b; Sellers et al., 1997; Sellers et al., 2000). Values ranged from 31 points (i.e. empty defect without repair tissue) to 0 points (normal articular cartilage, complete regeneration).

All images were acquired by a solid-state CCD camera (Olympus) mounted on a microscope (BX 45; Olympus) and analysed with the analySIS program (Soft Imaging System Corp., Munster, Germany) using standardised parameters, including light intensity. A total of 173 sections were scored independently and in a blinded fashion by three individuals.

\section{Statistical analysis}

Based on previous experiments (Kaul et al., 2006; Madry et al., 2005; Madry et al., 2011b; Orth et al., 2012b), we estimated standard deviation of $25 \%$ for the mean total score to determine sample size. For a power of $80 \%$ and a two-tailed alpha level of 0.05 , a sample size of 6 defects per group would be needed to detect a mean difference of 5 points between groups (assuming a pooled standard deviation of 2.5 points; effect size $=5 / 2.5=2.0$, using the two-sample Student's $t$-test (version 5.0, nQuery Advisor, Statistical Solutions, Saugus, MA, USA). To accommodate possible postoperative complications, each test condition was performed with 7 defects per group and time point for in vivo experiments.

Statistical analysis of the data was performed using the SPSS software package (version 12.0, SPSS Inc., Chicago, IL, USA). To evaluate the in vivo experiments, points for each category and total score were compared between the two groups using a mixed general linear model with repeated-measures (knees nested within the same animals). All continuous variables, including IGF-I production and histological scoring for parameters such as cell morphology, architecture and tidemark, were tested for normality using the Kolmogorov-Smirnov goodnessof-fit method and no significant skewness or kurtosis was detected. Therefore, continuous data are expressed in terms of the mean \pm SD or mean $\pm 95 \%$ confidence interval. Categorical data including type-I and type-II collagen immunoreactivity did not conform to a Gaussian distribution and were thus compared nonparametrically between the defects receiving lacZ versus IGF-I constructs using the Wilcoxon signed-ranks test. A two-tailed $P<0.05$ was considered statistically significant, shown in both figures and tables by superscripts of a.

\section{Results}

\section{Cellular characterisation of the $l a c Z$ and IGF-I constructs}

Transfection efficiency determined at day 3 after transfection was $37.3 \pm 8.2 \%(n=4)$. Cell viability at the time of dynamic seeding (one day after transfection) was $97.6 \pm 0.6 \%$ and $97.7 \pm 0.3 \%$ for $l a c Z$ - and IGF-Itransfected chondrocytes, respectively $(n=4, P>0.05)$. Seeding of lacZ- and IGF-I-transfected chondrocytes into PGA scaffolds was efficient, as indicated by the steady decline in the cell numbers of the seeding medium over the 2 days of seeding. At the time of transfer to the bioreactors, the lacZ and IGF-I constructs contained 2.5 \pm 0.1 and $2.6 \pm 0.1 \times 10^{6}$ viable chondrocytes, respectively 
( $n=14, P>0.05$ ) (Fig. 2). There was no difference in cell viability $(97.9 \pm 4.2 \%$ and $97.7 \pm 4.5 \%$, respectively, $n=2$, $P>0.05)$ and in the wet weights between groups at this time $(32.8 \pm 4.5$ and $34.6 \pm 4.5 \mathrm{mg}$, respectively, $n=14$, $P>0.05$ ), suggesting that transfection, expression of the transgenes, and scaffold material had no adverse effect upon chondrocyte viability and attachment. After $10 \mathrm{~d}$ in vitro, the IGF-I constructs had a 1.5-fold higher wet weight than the lac $Z$ constructs $(18.9 \pm 2.5$ and $12.4 \pm 2.1 \mathrm{mg}$, respectively; $n=14, P=0.003$ ). At $28 \mathrm{~d}$ of cultivation, the wet weight of the IGF-I constructs was 1.8 -fold higher than that of the $l a c Z$ constructs $(14.3 \pm 2.7 \mathrm{mg}$ and 7.8 \pm 1.8 , respectively; $n=7, P<0.001)$.

\section{Expression of the transgenes in vitro}

Mean transfection efficiency was $37.3 \pm 8.2 \%$. Mean IGF-I production by chondrocytes transfected with pCMVhIGF-I cultivated in monolayer was $186 \pm 37 \mathrm{ng} / \mathrm{L}$ x $10^{7}$ cells $/ 24 \mathrm{~h}$ $(n=2)$ on day 2 after transfection and $289 \pm 41 \mathrm{ng} / \mathrm{L} \mathrm{x} 10^{7}$ cells $/ 24 \mathrm{~h}(n=2)$ on day 4 . IGF-I constructs produced 2.21 $\pm 0.31 \mathrm{ng}$ IGF-I per construct/24 h $(n=3)$ on day 2 and $0.36 \pm 0.08 \mathrm{ng}$ IGF-I per construct/24 h $(n=3)$ on day 13 (day 10 of bioreactor cultivation) after transfection, and were significantly elevated until day $18(0.19 \pm 0.05 \mathrm{ng}$ IGF-I per construct/24 h; $n=3, P<0.05$ ) compared to lac $Z$ constructs (day 28 of bioreactor cultivation: $0.08 \pm 0.01 \mathrm{ng}$ IGF-I per construct/24 h; $n=3$ ). At all time points tested, the conditioned medium of the lac $Z$ constructs contained less than $0.08 \pm 0.02 \mathrm{ng}$ IGF-I per construct/24 h $(n=3)$.

\section{Implantation of genetically modified engineered constructs}

Macroscopic evaluation of treated knees after 28 weeks in vivo

Both types of constructs (lacZ and IGF-I constructs, each cultivated for 10 or $28 \mathrm{~d}$ in vitro) were next implanted into osteochondral defects. There was no effect of the differences in wet weight of the constructs on the press-fit implantation. No joint effusion, macroscopic synovialitis, heterotopic ossifications, or osteophytes were evident in

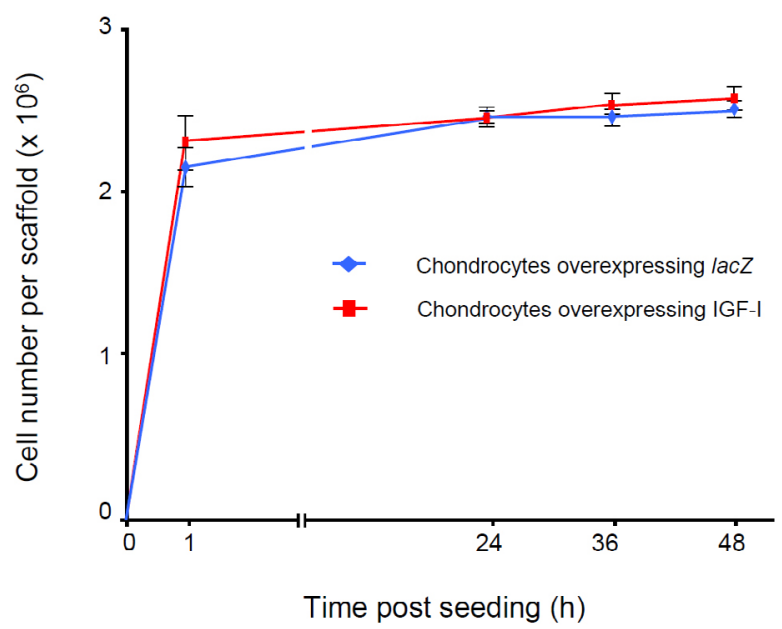

Fig. 2. Number of transfected articular chondrocytes overexpressing $l a c Z$ and IGF-I attached to the polymeric scaffolds in spinner flasks over time in vitro. Shown are the number of cells attached per polyglycolic acid (PGA) scaffold at the designated times during the $48 \mathrm{~h}$ course of dynamic seeding. Two days after initiating of the seeding, cell-polymer constructs were transferred into the rotating bioreactors.

any of the specimen at 28 weeks after transplantation. Semi-quantitative macroscopic evaluation of the repair tissue revealed a trend towards better scores for defects that received IGF-I constructs than those where lacZ constructs were implanted, regardless of the duration of cultivation in the bioreactor, without reaching statistical significance $(P>0.05)$ (Fig. 3).

Histological analysis of the synovial membrane after 28 weeks in vivo

Semi-quantitative evaluation of the constructs cultivated for $10 \mathrm{~d}$ in the bioreactor revealed a 1.9-fold lower (better) score for the synovial membrane of knee joints that received the IGF-I constructs compared with those where lacZ constructs were applied $(P>0.05)$ (Table 2). When constructs were cultivated for $28 \mathrm{~d}$ in the bioreactor,

Table 3. Effect of tissue-engineered constructs based on chondrocytes overexpressing IGF-I on the histological grading of the repair tissue $-10 \mathrm{~d}$ of bioreactor cultivation.

\begin{tabular}{|l|c|c|}
\hline \multirow{2}{*}{ Category } & lac $\boldsymbol{Z}$ constructs & IGF-I constructs \\
\cline { 2 - 3 } & Mean $(95 \% \mathrm{CI})$ & Mean $(95 \% \mathrm{CI})$ \\
\hline Filling of defect & $1.63(1.23-2.02)$ & $0.81(0.41-1.20)^{\mathrm{a}}$ \\
\hline Integration & $1.27(1.12-1.43)$ & $1.08(0.93-1.23)$ \\
\hline Matrix staining & $3.26(3.09-3.44)$ & $2.81(2.64-2.98)^{\mathrm{a}}$ \\
\hline Cellular morphology & $3.30(2.96-3.65)$ & $2.25(1.91-2.58)^{\mathrm{a}}$ \\
\hline Architecture of defect & $2.36(1.84-2.88)$ & $2.16(1.64-2.68)$ \\
\hline Architecture of surface & $2.53(2.14-2.91)$ & $2.57(2.18-2.95)$ \\
\hline Subchondral bone & $2.33(2.01-2.65)$ & $1.52(1.20-1.84)^{\mathrm{a}}$ \\
\hline Tidemark & $3.01(2.59-3.42)$ & $2.28(1.86-2.70)^{\mathrm{a}}$ \\
\hline Average total score & $\mathbf{1 9 . 7}(\mathbf{1 7 . 7}-\mathbf{2 1 . 7})$ & $\mathbf{1 5 . 4}(\mathbf{1 3 . 5}-\mathbf{1 7 . 5})^{\mathrm{a}}$ \\
\hline
\end{tabular}

Histological scoring is based on the complex system described by Sellers et al. (Sellers et al., 1997; Orth et al., 2012b). The score for a normal osteochondral unit is 0 points; an empty defect receives 31 points. ${ }^{\text {a }}$ Statistically significant treatment effect. $\mathrm{CI}=$ confidence interval. 
the score for the synovial membrane of knee joints that received IGF-I constructs was 1.8-fold lower (better) compared with those where $l a c Z$ constructs were applied $(n=6, P>0.05)$.

Immunological analysis of immune cell infiltration No immune cells infiltrating the defects of knees receiving either lacZ or IGF-I constructs were identified by immunohistochemical analysis of tissue sections using specific antibodies to detect CD3- (T-lymphocytes), CD11b- (activated macrophages), and HLA-DR $\alpha$ (class II MHC antigens) (data not shown).

\section{Expression of the transgenes in vivo}

Cytoplasmic immunoreactivity to $ß$-gal was present in about $5-10 \%$ of cells randomly distributed within the repair tissue of defects that received the $l a c Z$ constructs, with no preference for any cartilage layer and regardless of the duration of cultivation in the bioreactor (Fig. 4). IGF-I levels in the lavage fluids were not significantly different at 28 weeks between knee joints that received lacZ or IGF-I constructs $(11.6 \pm 2.2$ and $9.3 \pm 2.0 \mathrm{ng} / \mathrm{mL}$, respectively, $n=12, P>0.05)$. Immunoreactivity to IGF-I was always stronger in the repair tissue of defects that received IGF-I constructs than the $l a c Z$ constructs, regardless of the duration of cultivation in the bioreactor (Fig. 4).

\section{Articular cartilage repair and chondrogenesis in osteochondral defects by implantation of genetically modified tissue-engineered constructs in vivo}

Histological analysis of the repair tissue in vivo after transplantation of lacZ and IGF-I constructs cultivated for $10 \mathrm{~d}$ in bioreactors

Filling of the defect, matrix staining with Safranin O, cellular morphology, and restoration of the subchondral bone and of the tidemark were significantly improved in defects treated with IGF-I constructs compared with defects that received $l a c Z$ constructs (Table 3, Fig. 5). When the individual scores were combined, the average

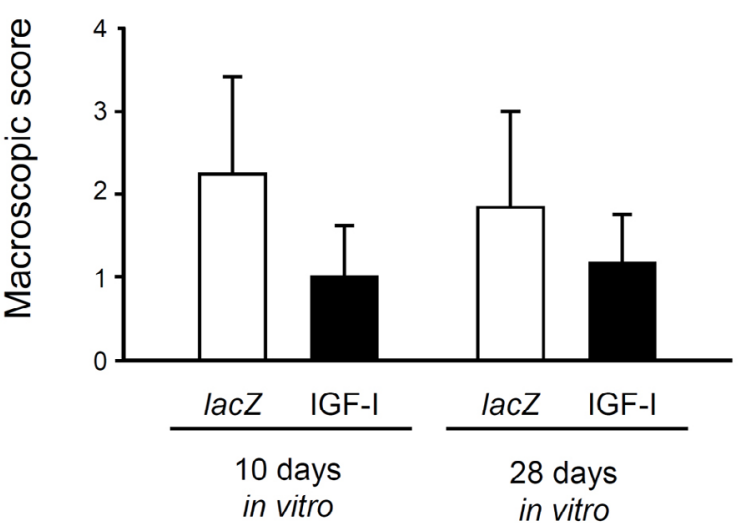

Fig. 3. Macroscopic articular cartilage repair by tissue-engineered constructs, based on chondrocytes overexpressing $l a c Z$ and IGF-I after 28 weeks of implantation. Data were obtained applying the inverse semi-quantitative score described in Table 1 by two blinded evaluators. A macroscopic normal joint and defect appearance would receive 0 points. Data are expressed as mean \pm S.D ( $P>0.05$ for all comparisons).

total score was significantly better for defects treated with the IGF-I constructs compared with those receiving the lac $Z$ constructs (15.4 and 19.7 points, respectively, $P<0.01$, Table 3).

Histological analysis of the repair tissue in vivo after transplantation of lacZ and IGF-I constructs that were cultivated for 28 in bioreactors

A repair tissue filled the cartilage defects treated with IGF-I constructs with a similar level to that of the surrounding normal articular cartilage, corresponding to the lowest (best) average individual score value $(0.53)$ of all categories evaluated at 28 weeks in vivo (Table 4), were significantly different when compared with defects receiving the lac $Z$ constructs. Similarly, individual score values for integration of the new tissue with the adjacent

Table 4. Effect of tissue-engineered constructs based on chondrocytes overexpressing IGF-I on the histological grading of the repair tissue $-28 \mathrm{~d}$ of bioreactor cultivation.

\begin{tabular}{|l|c|c|}
\hline \multirow{2}{*}{ Category } & lac $\boldsymbol{Z}$ constructs & IGF-I constructs \\
\cline { 2 - 3 } & Mean $(95 \% \mathrm{CI})$ & Mean $(95 \% \mathrm{CI})$ \\
\hline Filling of defect & $0.95(0.65-1.24)$ & $0.53(0.23-0.83)^{\mathrm{a}}$ \\
\hline Integration & $1.15(1.08-1.21)$ & $1.03(0.97-1.09)^{\mathrm{a}}$ \\
\hline Matrix staining & $2.44(2.04-2.83)$ & $2.47(2.07-2.86)$ \\
\hline Cellular morphology & $2.90(2.46-3.33)$ & $2.15(1.72-2.58)^{\mathrm{a}}$ \\
\hline Architecture of defect & $2.48(2.19-2.77)$ & $1.30(1.01-1.59)^{\mathrm{a}}$ \\
\hline Architecture of surface & $2.07(1.71-2.43)$ & $1.83(1.48-2.19)$ \\
\hline Subchondral bone & $2.11(1.79-2.44)$ & $1.93(1.61-2.26)$ \\
\hline Tidemark & $3.01(2.75-3.27)$ & $2.75(2.49-3.01)$ \\
\hline Average total score & $\mathbf{1 7 . 1}(\mathbf{1 5 . 4}-\mathbf{1 8 . 8})$ & $\mathbf{1 3 . 9}(\mathbf{1 2 . 2}-\mathbf{1 7 . 1})^{\mathrm{a}}$ \\
\hline
\end{tabular}

Histological scoring is based on the complex system described by Sellers et al. (Sellers et al., 1997; Orth et al., 2012b). The score for a normal osteochondral unit is 0 points; an empty defect receives 31 points. ${ }^{\text {a }}$ Statistically significant treatment effect. $\mathrm{CI}=$ confidence interval. 


\section{0 days in vitro}

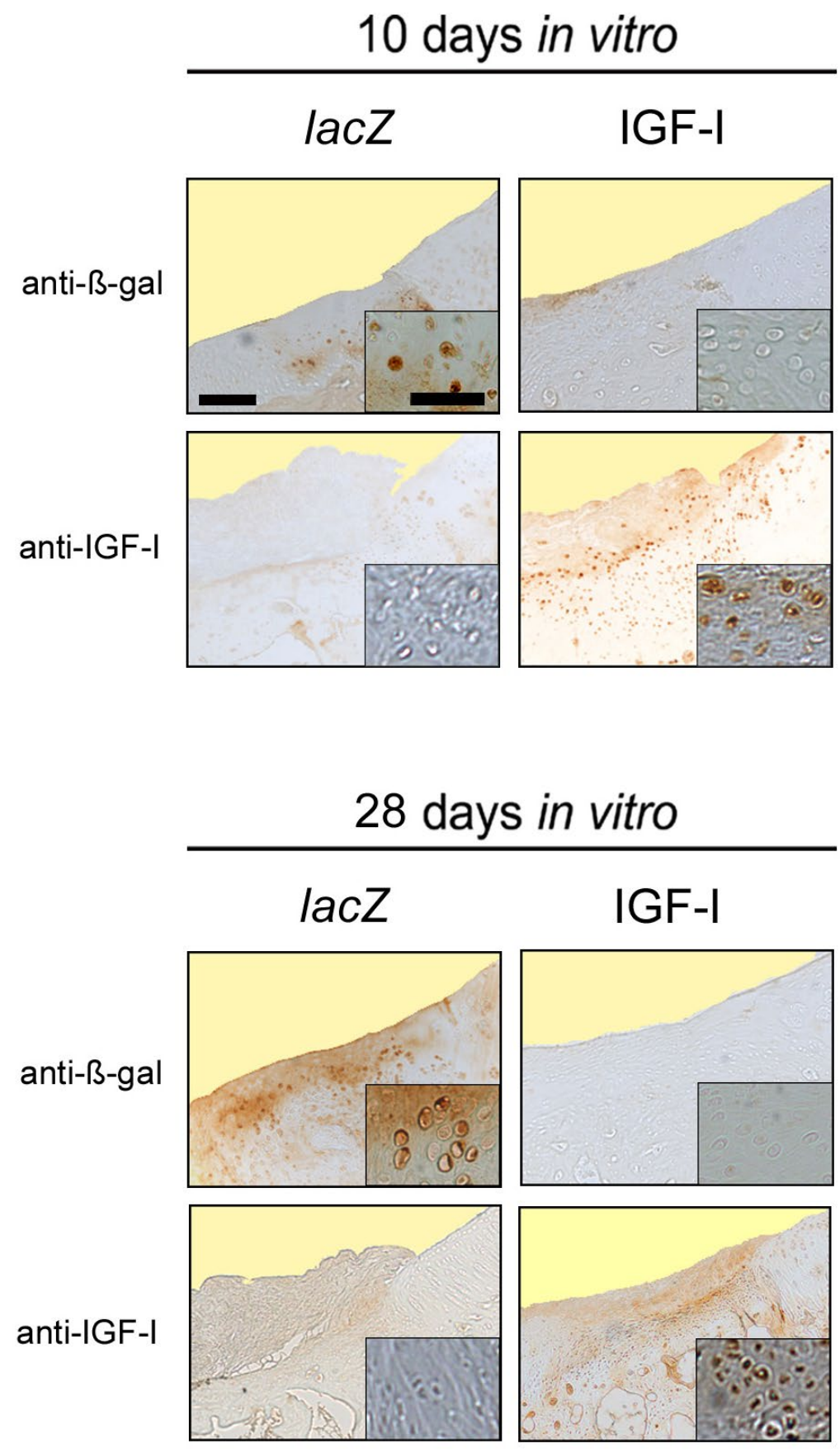

Fig. 4. Transgene expression in vivo. Representative histologic sections of the area of integration between the repair tissue (left side of each picture) with the adjacent articular cartilage (right side of each picture) of the osteochondral defects 28 weeks after the implantation of tissue-engineered constructs based on chondrocytes overexpressing $l a c Z$ (left columns) and IGF-I (right columns) after 10 (top 4 images) and $28 \mathrm{~d}$ (bottom 4 images) of bioreactor cultivation stained with an anti- $\beta$-gal and anti-IGF-I antibody. No immunoreactivity to $\beta$-gal was present in the cytoplasm of cells in the repair tissue of defects that received an IGF-I constructs at both time points. Immunoreactivity to $\beta$-gal was present in the cytoplasm of about 5-10\% of cells randomly distributed within in the repair tissue of defects that received the $l a c Z$ constructs at both time points. Immunoreactivity to IGF-I in the repair tissue is mainly located in the superficial and middle parts of the cartilaginous repair tissue of the defect receiving an IGF-I construct at 10 and 28 days. Photomicrographs were obtained using standardised photographic parameters, including light intensity. Insets are taken from the middle parts of the cartilaginous repair tissue. Scale bars $=300 \mu \mathrm{m}$, and $30 \mu \mathrm{m}$ (insets).

articular cartilage, cellular morphology and architecture were significantly improved for defects receiving IGF-I constructs compared with those receiving lac $Z$ constructs (Fig. 6). The average total score was also significantly better in the IGF-I constructs that were cultivated for $28 \mathrm{~d}$ in bioreactors in vitro compared with the lac $Z$ constructs (13.9 and 17.1 points, respectively; $P=0.01$ ).

Effect of IGF-I overexpression and duration of bioreactor cultivation on type-I and type-II collagen synthesis

Polarised light microscopy revealed collagen fibrils within the repair tissue of defects receiving both types of constructs, mainly oriented parallel to the joint surface without reproducing a hyaline articular cartilage organisation. Birefringence was weaker within the repair tissue than in the surrounding normal articular cartilage of both groups (Fig. 5 and 6). Birefringence in the subchondral bone was similar between the defect areas and the adjacent tissue.

Immunoreactivity to type-I collagen was stronger in the repair tissue of defects that received cartilaginous constructs composed of lacZ-modified chondrocytes than in those where the IGF-I constructs were applied, regardless of the duration of cultivation in the bioreactor (Fig. 7). No difference in immunoreactivity to type-I collagen was seen between both groups when cultivated for $10 \mathrm{~d}$ in the bioreactor in vitro $(P>0.05)$. Transplantation of lac $Z$ constructs that were cultivated for $28 \mathrm{~d}$ in vitro resulted in a 1.4-fold stronger immunoreactivity to type-I collagen compared with IGF-I constructs $(P>0.05)$. 


\section{0 days in vitro}

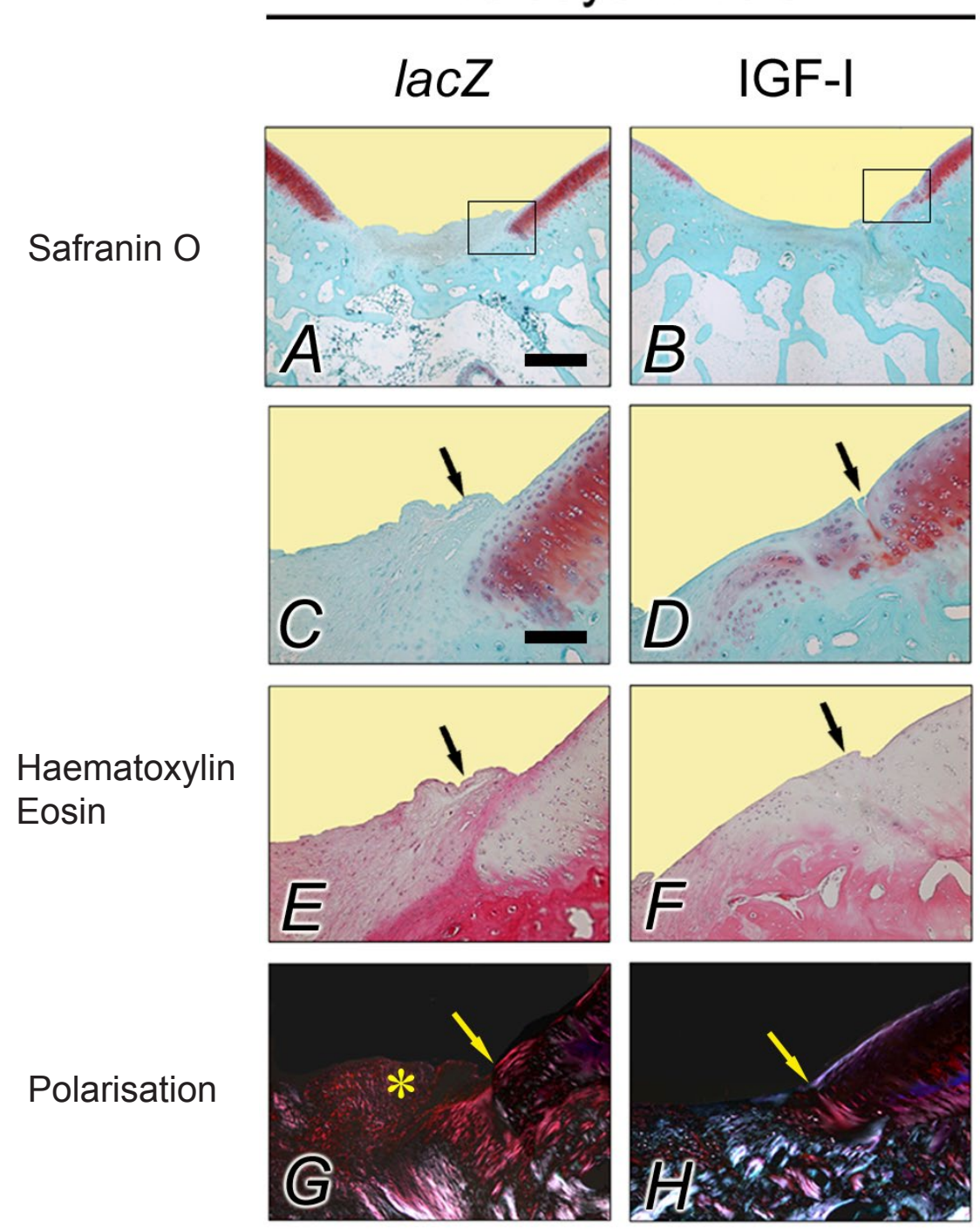

IGF-I

Fig. 5. Osteochondral repair following $10 \mathrm{~d}$ of in vitro bioreactor cultivation. Representative histologic sections of osteochondral defects 28 weeks after the implantation of tissue-engineered constructs based on chondrocytes overexpressing lacZ (left columns; $\boldsymbol{A}, \boldsymbol{C}, \boldsymbol{E}, \boldsymbol{G}$ ) and IGF-I (right columns; $\boldsymbol{B}, \boldsymbol{D}, \boldsymbol{F}, \boldsymbol{H}$ ) after $10 \mathrm{~d}$ of bioreactor cultivation. The top two images give an overview of the entire defect treated with a lacZ (left; $\boldsymbol{A})$ and IGF-I construct (right; $\boldsymbol{B})$ (Safranin O-fast green). Images below $(\boldsymbol{C}-\boldsymbol{H})$ are magnified views of the insets in the top two images, illustrating the area of integration (arrows) between the repair tissue (left side of each picture) with the adjacent articular cartilage (right side of each picture) (Safranin O-fast green; $\boldsymbol{A}-\boldsymbol{D})$. Note the difference in cellular morphology of the repair tissue between the groups, with less than $50 \%$ of round cells with the morphology of chondrocytes following transplantation of a lacZ construct (left; $\boldsymbol{E}$ ), compared with the repair tissue composed mostly of round cells with the morphology of chondrocytes following transplantation of an IGF-I construct (right; $\boldsymbol{F}$ ) (haematoxylin and eosin). The repair of the subchondral bone in the defect receiving an IGF-I construct is significantly improved (polarised light microscopy, right; $\boldsymbol{H}$ ), in contrast to the defect receiving a lacZ construct (left; $\boldsymbol{G}$ ). Here, a part of the repair tissue extends into the joint space; asterisk). All sections illustrated were taken from defects having a histological rating equal to the mean score for its respective treatment group. Photomicrographs were obtained using standardised photographic parameters, including light intensity. Scale bars = $1 \mathrm{~mm}(\boldsymbol{A}, \boldsymbol{B})$; and $300 \mu \mathrm{m}(\boldsymbol{C}-\boldsymbol{H})$.

Immunoreactivity to type-II collagen was always stronger in the repair tissue of defects that received IGF-I constructs than in those where the lac $Z$ constructs were applied, regardless of the duration of cultivation in the bioreactor (Fig. 8). Transplantation of IGF-I constructs that were cultivated for 10 days in the bioreactor in vitro resulted in a 1.9-fold stronger immunoreactivity to typeII collagen compared with lac $Z$ constructs $(P>0.05)$. Transplantation of IGF-I constructs that were cultivated for $28 \mathrm{~d}$ in the bioreactor in vitro led to a 1.6-fold stronger immunoreactivity to type-II collagen compared with lac Z constructs $(P>0.05)$. 


\section{8 days in vitro}

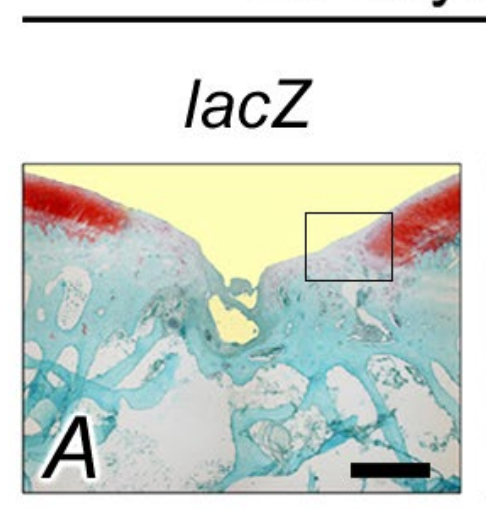

\section{IGF-I}

\section{Safranin O}

\section{Haematoxylin Eosin}
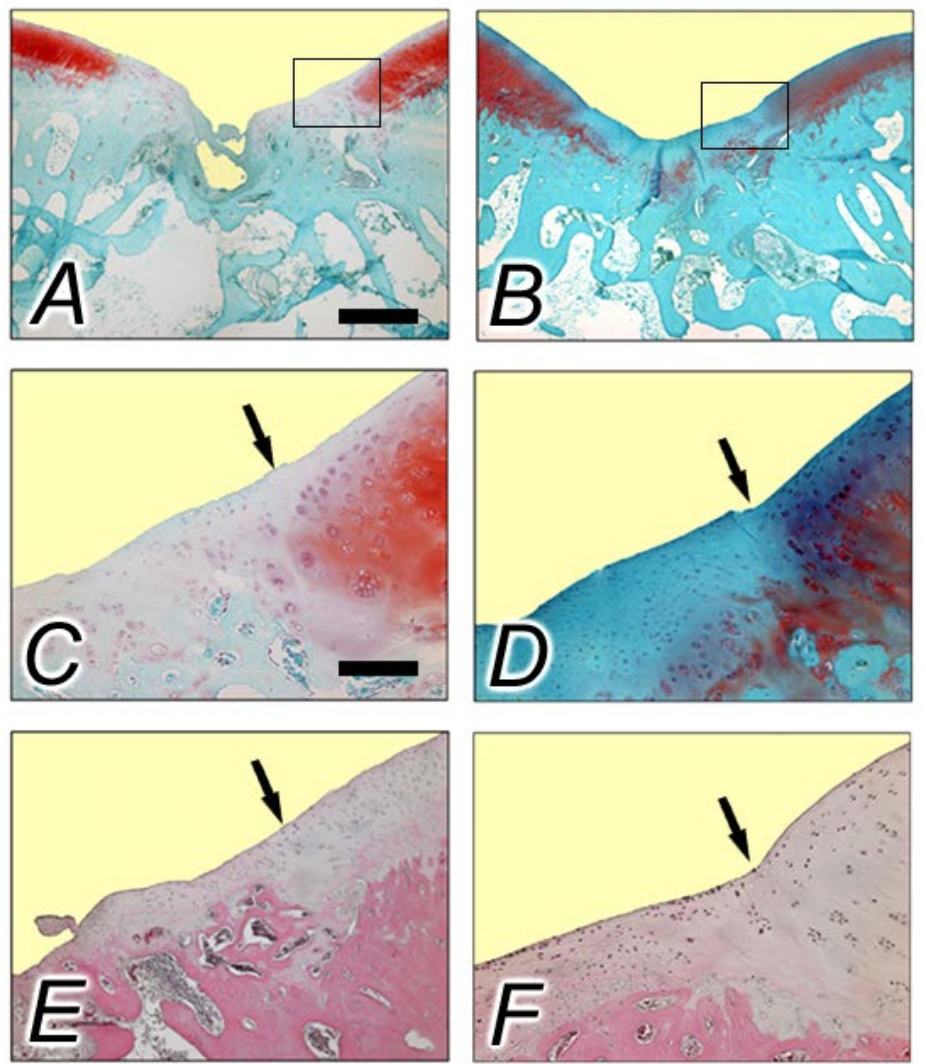

Haematoxylin
Eosin

\section{Polarisation}
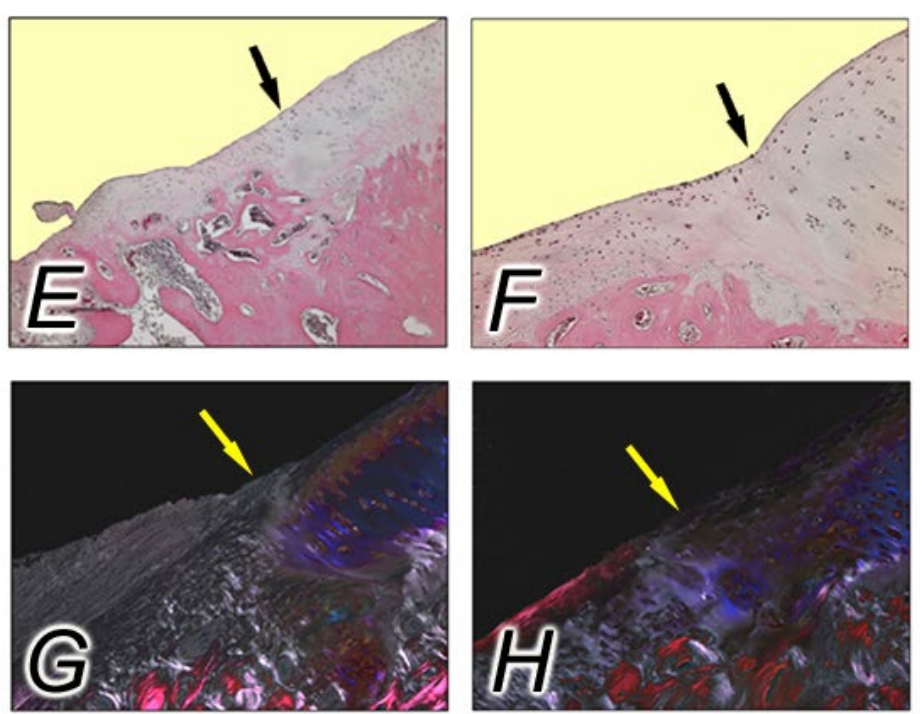

Fig. 6. Osteochondral repair following $28 \mathrm{~d}$ of in vitro bioreactor cultivation. Representative histologic sections of osteochondral defects 28 weeks after the implantation of tissue-engineered constructs based on chondrocytes overexpressing lacZ (left columns; $\boldsymbol{A}, \boldsymbol{C}, \boldsymbol{E}, \boldsymbol{G}$ ) and IGF-I (right columns; $\boldsymbol{B}, \boldsymbol{D}, \boldsymbol{F}, \boldsymbol{H}$ ) after $28 \mathrm{~d}$ of bioreactor cultivation in vitro. The top two images give an overview of the entire defect treated with a lac $Z$ (left; $\boldsymbol{A}$ ) and IGF-I construct (right; $\boldsymbol{B})$ (Safranin O-fast green). Images below $(\boldsymbol{C}-\boldsymbol{H})$ are magnified views of the insets in the top two images, illustrating the area of integration (arrows) between the repair tissue (left side of each picture) with the adjacent articular cartilage (right side of each picture) (Safranin O-fast green; $\boldsymbol{A}-\boldsymbol{D}$ ). Note the significantly lesser degree in filling of the defect and overall increased degeneration of the repair tissue following transplantation of a lac Z construct (left; $\boldsymbol{A}$ ) (Safranin O-fast green), the lesser developed cellular morphology following transplantation of a lac $Z$ construct (left; $\boldsymbol{E}$ ) compared with the cellular morphology following transplantation of an IGF-I construct (right; $\boldsymbol{F}$ ) (haematoxylin and eosin), together with the significantly improved restoration of the subchondral bone (polarised light microscopy, right; $\boldsymbol{H}$ ). Photomicrographs were obtained using standardised photographic parameters, including light intensity Scale bars $=1 \mathrm{~mm}(\boldsymbol{A}, \boldsymbol{B})$; and $300 \mu \mathrm{m}(\boldsymbol{C}-\boldsymbol{H})$.

Osteoarthritic changes in the articular cartilage adjacent to the osteochondral defects

Osteoarthritic changes in the cartilage adjacent to the defects were worse following transplantation of lacZ constructs cultivated for $10 \mathrm{~d}$ in vitro compared with IGF-I constructs (1.8-fold; $P>0.05)$ (Fig. 9). Transplantation of lac $Z$ constructs that were cultivated for $28 \mathrm{~d}$ in vitro also resulted in a 2.5-fold higher (worse) score for osteoarthritis in the adjacent articular cartilage, significantly different compared to IGF-I constructs $(P=0.007)$. 


\section{Type I collagen}

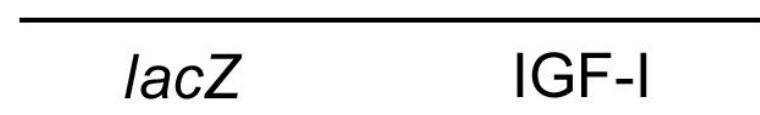

Fig. 7. Immunoreactivity to type-I collagen in the repair tissue and adjacent articular cartilage following 10 and $28 \mathrm{~d}$ of bioreactor cultivation. (a) Representative sections of the cartilaginous repair tissue of the defects 28 weeks after the implantation of tissue-engineered constructs based on chondrocytes overexpressing lacZ (left column) and IGF-I (right column) after $10 \mathrm{~d}$ (top images) or $28 \mathrm{~d}$ (bottom images) of bioreactor cultivation stained with a monoclonal mouse antihuman type-I collagen IgG. A large part of the superficial repair tissue in the defect receiving a lac $Z$ construct (following $10 \mathrm{~d}$ of bioreactor cultivation) is degenerated and extends both into the joint space and onto the adjacent articular cartilage; asterisk). The cartilaginous repair tissue in defects receiving $l a c Z$ is characterised by a higher degree of immunoreactivity to type-I collagen, compared with defects receiving IGF-I constructs. Arrows illustrate the area of integration between the repair tissues (left side of each picture) with the adjacent articular cartilage (right side of each picture). All sections were taken from defects having a rating equal to the mean score for its respective treatment group. Scale bar $=300 \mu \mathrm{m}$. (b) Semi-quantitative evaluation of the immunoreactivity to type-I collagen. Data are expressed as mean \pm S.D ( $P>0.05$ for all comparisons).
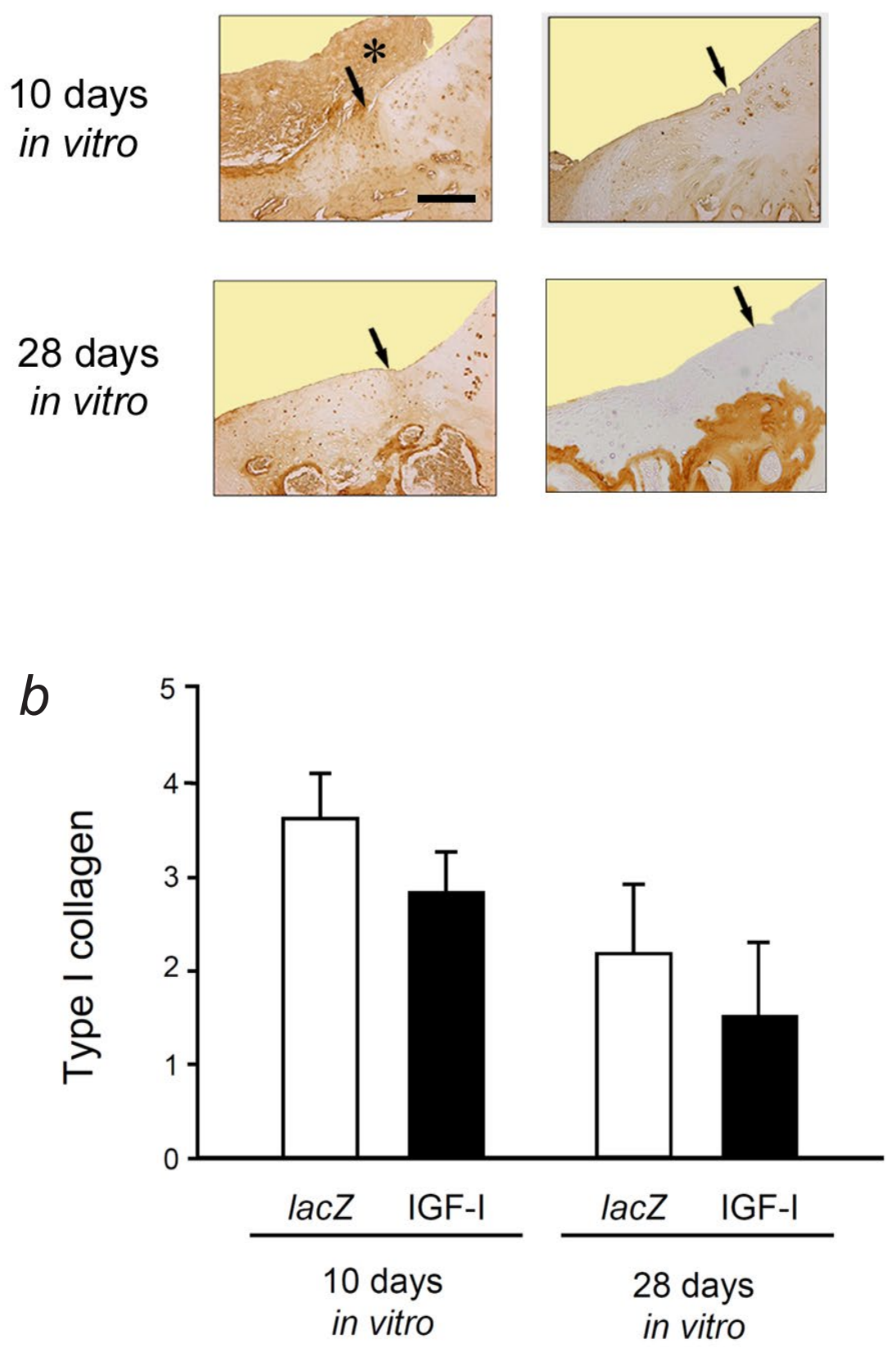

Effect of the duration of bioreactor cultivation in vitro on the quality of the repair tissue in vivo

A statistical comparison between the two time points (10 versus $28 \mathrm{~d}$ ) within each single treatment group (lacZ and IGF-I) was performed. Among the lac $Z$ constructs, filling of the defect $(P=0.04)$ and matrix staining $(P=0.01)$ were improved when the constructs were cultivated for $28 \mathrm{~d}$ compared with $10 \mathrm{~d}$. For all other individual parameters, the duration of bioreactor cultivation did not influence overall repair, as reflected in the similar total score $(P>0.05)$.

For the IGF-I constructs, a comparison for each single parameter between the 10 and $28 \mathrm{~d}$ of cultivation groups revealed significantly better repair at $28 \mathrm{~d}$ with respect to filling $(P=0.03)$, architecture of the $\operatorname{defect}(P<0.01)$, and architecture of the surface $(P<0.01)$. Other individual categories were not significantly different between 10 and $28 \mathrm{~d}$. The average total score of the IGF-I constructs was significantly improved after $28 \mathrm{~d}$ of bioreactor cultivation compared with $10 \mathrm{~d}(P=0.02)$, in contrast to the lac $Z$ constructs. This was also reflected in the lowest (best) total score value (13.9) of all 4 groups. 


\section{Type II collagen}

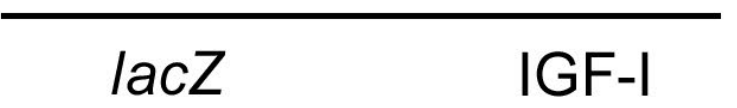

Fig. 8. Immunoreactivity to typeII collagen in the repair tissue and adjacent articular cartilage following 10 and $28 \mathrm{~d}$ of bioreactor cultivation. (a) Representative sections of the cartilaginous repair tissue of the defects 28 weeks after the implantation of tissue-engineered constructs based on chondrocytes overexpressing lacZ (left column) and IGF-I (right column) after $10 \mathrm{~d}$ (top images) or $28 \mathrm{~d}$ (bottom images) of bioreactor cultivation stained with a monoclonal mouse anti-human typeII collagen IgG. Immunoreactivity to type-II collagen is mostly present in the repair tissue of defects receiving IGF-I constructs. In contrast, there is less immunoreactivity in the repair tissue of the defects receiving $l a c Z$ constructs. Here, the superficial layers of the repair tissue are degenerated and extend into the joint space and onto the adjacent articular cartilage (asterisk). Arrows illustrate the area of integration between the repair tissue (left side of each picture) with the adjacent articular cartilage (right side of each picture). All sections were taken from defects having a rating equal to the mean score for its respective treatment group. Scale bar $=300 \mu \mathrm{m}$. (b) Semi-quantitative evaluation of the immunoreactivity to type-II collagen. Data are expressed as mean \pm S.D $(P>0.05$ for all comparisons).
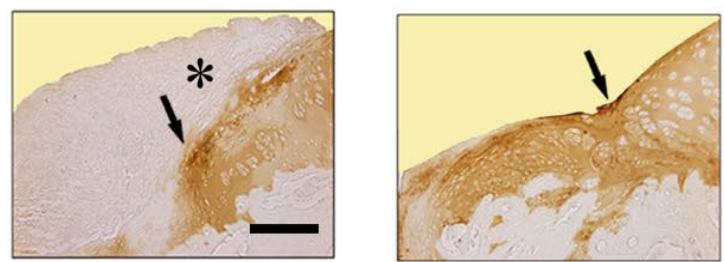

\section{0 days in vitro}
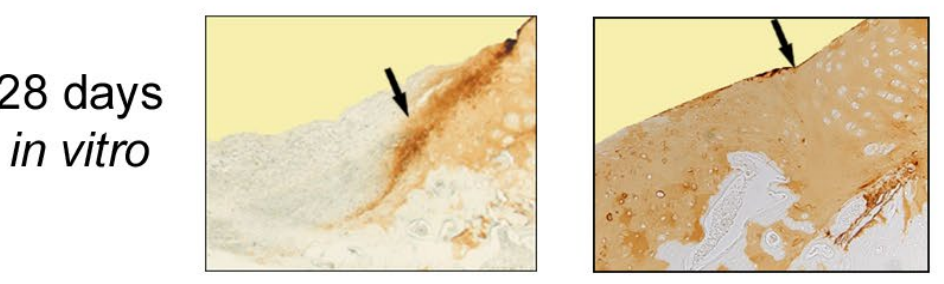

$b$

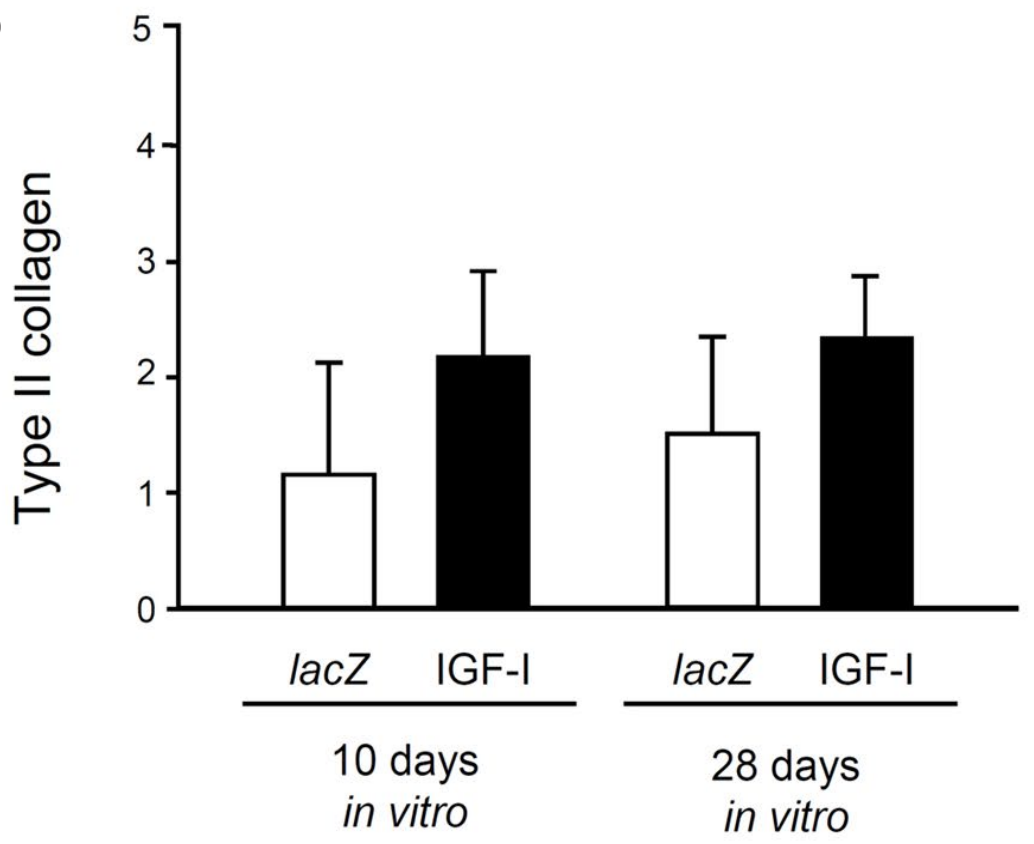

\section{Discussion}

Combining tissue engineering and gene therapy may be beneficial compared with cell transplantation or gene transfer alone. We investigated if overexpression of a human insulin-like growth factor I (IGF-I) gene in chondrocytes used to engineer cartilage can enhance the repair of osteochondral defects in a rabbit model.

The present study has three major new findings. First, overexpression of a human IGF-I cDNA in tissueengineered cartilaginous constructs enhances the repair of osteochondral defects in a rabbit model after 28 weeks in vivo, regardless whether the constructs were cultivated for 10 or $28 \mathrm{~d}$ in vitro. Second, maximal promotion of cartilage repair was initiated following implantation of IGF-I constructs subjected to a longer cultivation period (cultivated for $28 \mathrm{~d}$ in vitro). Third, lesser osteoarthritic changes in the cartilage adjacent to the defects resulted when IGF-I constructs cultivated for $28 \mathrm{~d}$ in vitro were transplanted.

This in vivo study is a direct translation of previous work in vitro which showed that gene transfer of a human IGF-I cDNA enhanced both structural and functional parameters of tissue-engineered cartilage (Madry et al., 2002). To the best of our knowledge, the present study is the first that moved the concept of IGF-I overexpression to 
a

Fig. 9. Osteoarthritic changes in the articular cartilage adjacent to the defects in the trochlea after 28 weeks in vivo. (a) Representative histologic sections of the articular cartilage adjacent to the osteochondral defects 28 weeks after the implantation of tissueengineered constructs based on chondrocytes overexpressing lacZ (left column) and IGF-I (right column) after $10 \mathrm{~d}$ (top images) or $28 \mathrm{~d}$ (bottom images) of bioreactor cultivation in vitro. All sections represent a $2 \mathrm{~mm}^{2}$ area of articular cartilage adjacent to the defect (excluding the area of integration that is independently scored) and have a histological rating equal to the mean score for its respective treatment group. Insets are highly magnified views of representative regions of the middle zone of the articular cartilage. Photomicrographs were obtained using standardised photographic parameters, including light intensity. Safranin $\mathrm{O}$-fast green. Scale bar $=250 \mu \mathrm{m}$. (b) Semiquantitative microscopic evaluation of osteoarthritis changes in the articular cartilage adjacent to the defect in the trochlea after 28 weeks in vivo were evaluated using a grading system according to Solchaga et al. (2000), which includes single parameters of cellularity, staining intensity and cluster formation. Data are expressed as mean \pm S.D.
lacZ
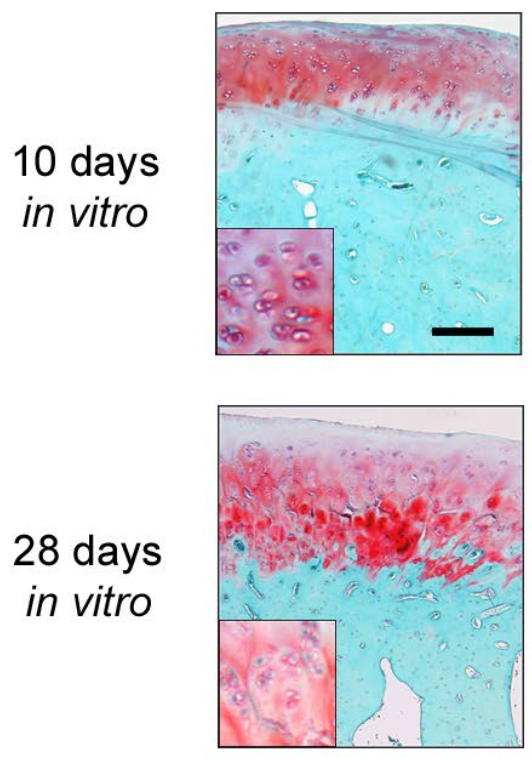

$b$ improve tissue engineering of cartilage to an animal model and investigated the effects of two different periods of in vitro construct cultivation, both on cartilage repair and osteoarthritis development in the adjacent cartilage.

The most important finding was the enhanced cartilage repair following overexpression of IGF-I tissue-engineered constructs in vivo. As the animals were allowed unrestricted activity postoperatively under full-load bearing to maximise exposure of the defects to loading, these data suggest that even under physiological loads, resilience was better for the IGF-I-treated defects than for the controls. This approach may be advantageous compared to the implantation of isolated native (Brittberg et al., 1994) or genetically modified (Madry et al., 2011a; Madry et al., 2011b) cells or to direct gene transfer approaches (Evans et al., 2011). So far, only few studies have been performed to test the concept of tissue-engineered cartilage based on genetically modified cells for articular cartilage repair. Chondrocytes transfected with a bone morphogenetic protein 7 (BMP-7) gene and encapsulated in collagenfibrin gels that were statically cultured for 2 weeks led to improved repair of cartilage defects after 12 weeks in rabbits in vivo (Che et al., 2010). When de-differentiated rabbit chondrocytes transduced ex vivo with a recombinant baculoviral BMP-2 vector were cultured in scaffolds for 3 weeks, cartilage repair was improved at 8 weeks following transplantation in rabbit osteochondral defects (Chen et al., 2009).

Previous in vivo studies have demonstrated the potential of IGF-I delivered as protein to enhance the repair of 
experimental chondral (Hunziker and Rosenberg, 1996) and osteochondral defects (Fortier et al., 2002; Nixon et al., 1999). Similarly, improved repair also resulted following transplantation of IGF-I-overexpressing isolated cells such as adenovirally-transduced perichondrial cells (Gelse et al., 2003) and transfected (Madry et al., 2005; Orth et al., 2011) or adenovirally-transduced articular chondrocytes (Goodrich et al., 2007). Interestingly, the positive immunoreactivity to type-I and -II collagen supports (fibro-) cartilaginous repair of the defect, whereas Safranin O staining of the same tissues was lower compared with previous studies without or with transplantation of IGF-I-overexpressing cells (Madry et al., 2005; Madry et al., 2011b; Orth et al., 2012a; Orth et al., 2011). When related to the results following implantation of IGF-Ioverexpressing articular chondrocytes in alginate spheres, average total score values for both control and treatment groups were better after 14 weeks in vivo compared to the results after 28 weeks of the present study (Madry et al., 2005; Orth et al., 2012a; Orth et al., 2011). Whether these discrepancies are due to differences in the structure of the repair tissue at the different observation times in vivo or reflect a possible effect of the scaffold biomaterial on proteoglycan deposition remains to be determined.

Providing an IGF-I gene sequence via a tissueengineered construct allows for a spatially defined delivery of a therapeutic factor to articular cartilage defects while simultaneously supplying a template filling the defect (Evans, 2011; Ivkovic et al., 2011). For example, when porous collagen-glycosaminoglycan scaffolds were loaded with IGF-I, a large part of the protein was released as a burst within the first day (Mullen et al., 2010). Here, secretion of IGF-I was significantly elevated until day 18 compared to $l a c Z$ constructs. Of note, levels of IGF-I in the conditioned medium may not reflect the total extent of transgene expression, as some of the IGF-I may have been associated with the newly deposited extracellular matrix of the constructs, possibly potentiating its effects (Jones et al., 1993). The positive immunoreactivities to ß-gal and IGF-I in the respective repair tissues of defects indicates prolonged expression of the transgene and presence of the growth factor following orthotopic implantation, as the half-life of free IGF-I is very short (Frystyk et al., 1999). This IGF-I produced by the chondrocytes within the tissue-engineered construct may have not only autocrine, but also paracrine effects on the mesenchymal cells from the subchondral bone marrow, as IGF-I can induce chondrogenesis in mesenchymal stem cells (Im et al., 2006; Longobardi et al., 2006; Uebersax et al., 2008). In contrast, IGF-I levels in the synovial fluid were normal - a desirable outcome for a possible clinical translation - where intraand extra-articular side-effects of the therapeutic factor need to be avoided. Also, IGF-I overexpression did not result in adverse effects such as synovitis or infiltration of immune cells. These data are consistent with preceding reports (Brower-Toland et al., 2001; Madry et al., 2005; Madry et al., 2002; Smith et al., 2000) and correspond well with the normal IGF-I levels already after day 4 post-operation when 25,000 ng recombinant IGF-I (a $\sim 1,000$-fold higher dose than the $\sim 2.2 \mathrm{ng}$ secreted by the constructs on day 2) were applied to osteochondral defects in a horse model (Fortier et al., 2002). Such normal IGF-I levels may likely result from a decreased clearance of the IGF-I caused by its retention within the newly formed cartilaginous matrix of the repair tissue, for example by interaction with IGF-I binding proteins (Garcia et al., 2003; Sah et al., 1994; Weimer et al., 2012; Yoon and Fisher, 2008), increased binding to IGF-I receptors and extracellular matrix components, and/or elution of the protein. Altogether, this suggests that at least some of the transfected, transplanted allogeneic chondrocytes continue to produce the growth factor within their new matrix (besides the endogenous IGF-I). Transgene expression in cartilage defects has been previously shown to last for at least 36 weeks in vivo, following implantation of allogeneic chondrocytes modified by adenoviral-mediated gene transfer in fibrin glue into osteochondral defects in an equine model (Hidaka et al., 2003). With the potential use of alternative strategies (e.g., use of viral vectors), transfection efficiency and expression of the transgene in vivo may be further increased (Cucchiarini et al., 2005; Kupcsik et al., 2009).

Another key finding is the influence of the in vitro cultivation period (Sekiya et al., 2002) of the engineered cartilage on defect repair in vivo. Jin et al. (2010) reported better repair when using mature constructs. Histological scores were also improved when engineered cartilage, based on BMP-2 overexpressing chondrocytes, was cultured for 3 weeks compared with 1-week cultivation (Chen et al., 2009). Interestingly, immature constructs from non-modified chondrocytes with lesser mechanical properties allowed for a better integration (Khan et al., 2008) than mature constructs (Obradovic et al., 2001). We have previously shown that engineered cartilage composed of genetically modified chondrocytes overexpressing IGF-I contains 10 -fold more glycosaminoglycans, 2-fold more collagens, and 1.5-fold more DNA and had a 3.6-fold higher equilibrium modulus than constructs based on lacZoverexpressing chondrocytes after 28 days in vitro (Madry et al., 2002). In general, the morphological, biochemical, and biomechanical characteristics of engineered cartilage composed of naïve (Freed et al., 1998) and genetically modified chondrocytes (Madry et al., 2002) continue to improve for at least the first 4-6 weeks of bioreactor culture in vitro, (Freed et al., 1998; Madry et al., 2002; Miot et al., 2012; Miot et al., 2006). Thus, more mature constructs contain more cells and extracellular matrix, reflected by an increase in Safranin O staining intensity (Madry et al., 2002), which may protect the chondrocytes from mechanical stresses in vivo (Ball et al., 2004), together with persisting transgene expression (Madry et al., 2002). These improved structural characteristics, as well as a possibly higher concentration of paracrine factors secreted by the higher number of cells within the constructs may be involved in the enhanced repair process. Of note, construct maturity - as determined by the wet weights of the IGF-I constructs - was significantly higher than in lacZ constructs at both time points in vitro, highlighting the positive effect of IGF-I on structural parameters of tissue-engineered cartilage in vitro (Madry et al., 2002). The decreasing wet weights of constructs of both groups over time most likely result from a degradation and resorption of the scaffold 
that exceeded the deposition of new matrix, as also seen in other cell-scaffold systems (Meinel et al., 2004). These findings underscore the importance of the duration of the in vitro cultivation period for articular cartilage repair based on tissue-engineered constructs in vivo (Deponti et al., 2012; Miot et al., 2012).

A clinically very critical consequence of a cartilage defect is the osteoarthritic degeneration (Martel-Pelletier et al., 2008) of the adjacent cartilage (Lefkoe et al., 1993; Schinhan et al., 2012). Importantly, implantation of IGF-I constructs cultivated for $28 \mathrm{~d}$ in vitro led to a significantly reduced degree of osteoarthritis in the adjacent articular cartilage. It is possible that the improved defect repair translated into a better resilience to withstand the loads applied to the defects. However, it may also represent a protective paracrine effect of the secreted IGF-I on the adjacent articular cartilage (Clemmons et al., 2002; Martel-Pelletier et al., 1998; Rogachefsky et al., 1993). Although upregulation of IGF-I gene expression has been demonstrated in human osteoarthritic articular cartilage (Middleton and Tyler, 1992), the response of osteoarthritic chondrocytes to IGF-I is reduced (Loeser et al., 2000). In addition, the duration of transgene expression in vivo could play a role. Osteoarthritic changes in human cartilage decreased following targeted overexpression of IGF-I in situ after $90 \mathrm{~d}$ (Weimer et al., 2012). In the present study, IGF-I expression was prolonged in IGF-I constructs of both cultivation periods in vivo. Whether the maturity of the cartilaginous construct affects the duration of transgene expression in vivo may be the subject of further studies.

Limitations of this study include: the lack of a detailed in vitro evaluation of the constructs implanted in the present study; the use of a small animal model as opposed to a larger animal; the lack of a time-course of transgene expression in vivo; the absence of a biomechanical evaluation of the constructs and the repair tissue, as well as animal gait analysis.

As the experimental foundation to generate cartilage by means of tissue engineering is well established (Angele et al., 1999; Freed et al., 1999; Grad et al., 2011; Langer and Vacanti, 1993; Martin et al., 2007; Mikos et al., 2006; Stoddart et al., 2009), its principle has already found entry into the surgical treatment of large symptomatic articular cartilage defects - as evidenced by the widespread use of matrix-induced autologous chondrocyte implantation (ACI), where the cells are attached to a biodegradable scaffold (Brittberg, 2009). Such supportive biomaterials may be similarly used to culture genetically modified human articular chondrocytes in bioreactors, with the aim of a spatially controlled application of the modified chondrocytes in vivo. When delivered in a clinical setting, a construct that actively supports chondrogenesis would then fill the focal cartilage defect (Madry and Cucchiarini, 2011). In view of this consideration, further steps are necessary to move this approach towards a clinical translation. These include proofs of its safety in preclinical and clinical trials, the selection of the optimal therapeutic gene, the establishment of the optimal cell number per defect surface area needed for implantation and the choice of an appropriate gene vector system that allows for efficient gene transfer and controlled gene expression
(Madry and Cucchiarini, 2011). Here, low-level, longterm transgene expression may be more appropriate when compared to high-level, short-term gene expression as the repair tissue develops over a long period of time (Safran and Seiber, 2010; Madry et al., 2011a). Ex vivo nonviral gene transfer provides such characteristics and therefore holds clinical potential (Al-Dosari and Gao, 2009). During the bioreactor cultivation, the cartilaginous constructs may additionally be subjected to direct mechanical forces (Salzmann et al., 2009), allowing for an even more defined stimulation based on the interaction between growth- or transcription-factors and dynamic loading (Kupcsik et al., 2009; Mauck et al., 2003).

In summary, application of gene transfer to cartilage tissue engineering opens doors that would remain closed to either technology working alone. This concept of genetically enhanced tissue engineering of cartilage may be used to evaluate the effect on articular cartilage repair of genes involved in chondrogenesis. It may also provide improved future clinical treatment options for acute cartilage defects.

\section{Conclusions}

Spatially defined delivery of a gene sequence within a tissueengineered cartilaginous construct that actively supports chondrogenesis enhances the repair of osteochondral defects in vivo. Genetically enhanced tissue engineering provides a versatile tool to evaluate potential therapeutic genes and to improve our comprehension of the process of new tissue formation within articular cartilage defects. Insights gained with additional explorations using this model may lead to more effective treatment options for acute cartilage defects.

\section{Acknowledgements}

We thank T. Thurn for expert technical assistance. Supported by the Deutsche Forschungsgemeinschaft (DFG MA $2363 / 1-1$ and 1-3 to H.M.). We wish to confirm that there are no known conflicts of interest associated with this publication and there has been no significant financial support for this work that could have influenced its outcome.

\section{References}

Al-Dosari MS, Gao X (2009) Nonviral gene delivery: principle, limitations, and recent progress. AAPS J 11: 671-681.

Angele P, Kujat R, Nerlich M, Yoo J, Goldberg V, Johnstone B (1999) Engineering of osteochondral tissue with bone marrow mesenchymal progenitor cells in a derivatized hyaluronan-gelatin composite sponge. Tissue Eng 5: 545-554.

Ball ST, Goomer RS, Ostrander RV, Tontz WL, Jr., Williams SK, Amiel D (2004) Preincubation of tissue engineered constructs enhances donor cell retention. Clin Orthop Relat Res 420: 276-285. 
Brittberg M (2009) Cell carriers as the next generation of cell therapy for cartilage repair: a review of the matrixinduced autologous chondrocyte implantation procedure. Am J Sports Med 38: 1259-1271.

Brittberg M, Lindahl A, Nilsson A, Ohlsson C, Isaksson O, Peterson L (1994) Treatment of deep cartilage defects in the knee with autologous chondrocyte transplantation. N Engl J Med 331: 889-895.

Brower-Toland BD, Saxer RA, Goodrich LR, Mi Z, Robbins PD, Evans CH, Nixon AJ (2001) Direct adenovirus-mediated insulin-like growth factor I gene transfer enhances transplant chondrocyte function. Hum Gene Ther 12: 117-129.

Che JH, Zhang ZR, Li GZ, Tan WH, Bai XD, Qu FJ (2010) Application of tissue-engineered cartilage with BMP-7 gene to repair knee joint cartilage injury in rabbits. Knee Surg Sports Traumatol Arthrosc 18: 496-503.

Chen HC, Chang YH, Chuang CK, Lin CY, Sung LY, Wang YH, Hu YC (2009) The repair of osteochondral defects using baculovirus-mediated gene transfer with de-differentiated chondrocytes in bioreactor culture. Biomaterials 30: 674-681.

Clemmons DR, Busby WH, Jr., Garmong A, Schultz DR, Howell DS, Altman RD, Karr R (2002) Inhibition of insulin-like growth factor binding protein 5 proteolysis in articular cartilage and joint fluid results in enhanced concentrations of insulin-like growth factor 1 and is associated with improved osteoarthritis. Arthritis Rheum 46: 694-703.

Cucchiarini M, Madry H (2005) Gene therapy for cartilage defects. J Gene Med 7: 1495-1509.

Cucchiarini M, Madry H, Ma C, Thurn T, Zurakowski D, Menger MD, Kohn D, Trippel SB, Terwilliger EF (2005) Improved tissue repair in articular cartilage defects in vivo by rAAV-mediated overexpression of human fibroblast growth factor 2. Mol Ther 12: 229-238.

Dell'accio F, Vincent TL (2010) Joint surface defects: clinical course and cellular response in spontaneous and experimental lesions. Eur Cell Mater 20: 210-217.

Deponti D, Di Giancamillo A, Mangiavini L, Pozzi A, Fraschini G, Sosio C, Domeneghini C, Peretti GM (2012) Fibrin-based model for cartilage regeneration: tissue maturation from in vitro to in vivo. Tissue Eng Part A 18: 1109-1122.

Evans CH (2011) Barriers to the clinical translation of orthopedic tissue engineering. Tissue Eng Part B Rev 17: 437-441.

Evans CH, Ghivizzani SC, Smith P, Shuler FD, Mi Z, Robbins PD (2000) Using gene therapy to protect and restore cartilage. Clin Orthop: S214-219.

Evans CH, Ghivizzani SC, Robbins PD (2011) Getting arthritis gene therapy into the clinic. Nat Rev Rheumatol 7: 244-249.

Fortier LA, Mohammed HO, Lust G, Nixon AJ (2002) Insulin-like growth factor-I enhances cell-based repair of articular cartilage. J Bone Joint Surg Br 84: 276-288.

Freed LE, Grande DA, Lingbin Z, Emmanual J, Marquis JC, Langer R (1994) Joint resurfacing using allograft chondrocytes and synthetic biodegradable polymer scaffolds. J Biomed Mater Res 28: 891-899.
Freed LE, Hollander AP, Martin I, Barry JR, Langer R, Vunjak-Novakovic G (1998) Chondrogenesis in a cellpolymer-bioreactor system. Exp Cell Res 240: 58-65.

Freed LE, Martin I, Vunjak-Novakovic G (1999) Frontiers in tissue engineering. In vitro modulation of chondrogenesis. Clin Orthop Relat Res 367: S46-58.

Frystyk J, Hussain M, Skjaerbaek C, Porksen N, Froesch ER, Orskov H (1999) The pharmacokinetics of free insulin-like growth factor-I in healthy subjects. Growth Horm IGF Res 9: 150-156.

Garcia AM, Szasz N, Trippel SB, Morales TI, Grodzinsky AJ, Frank EH (2003) Transport and binding of insulin-like growth factor I through articular cartilage. Arch Biochem Biophys 415: 69-79.

Gelse K, von der Mark K, Aigner T, Park J, Schneider H (2003) Articular cartilage repair by gene therapy using growth factor-producing mesenchymal cells. Arthritis Rheum 48: 430-441.

Goldring MB, Goldring SR (2010) Articular cartilage and subchondral bone in the pathogenesis of osteoarthritis. Ann N Y Acad Sci 1192: 230-237.

Goodrich LR, Hidaka C, Robbins PD, Evans CH, Nixon AJ (2007) Genetic modification of chondrocytes with insulin-like growth factor-1 enhances cartilage healing in an equine model. J Bone Joint Surg Br 89: 672-685.

Grad S, Eglin D, Alini M, Stoddart MJ (2011) Physical stimulation of chondrogenic cells in vitro: a review. Clin Orthop Relat Res 469: 2764-2772.

Hidaka C, Goodrich LR, Chen CT, Warren RF, Crystal RG, Nixon AJ (2003) Acceleration of cartilage repair by genetically modified chondrocytes overexpressing bone morphogenetic protein-7. J Orthop Res 21: 573-583.

Hunziker EB (2002) Articular cartilage repair: basic science and clinical progress. A review of the current status and prospects. Osteoarthritis Cartilage 10: 432-463.

Hunziker EB (2009) The elusive path to cartilage regeneration. Adv Mater 21: 3419-3424.

Hunziker EB, Rosenberg LC (1996) Repair of partialthickness defects in articular cartilage: cell recruitment from the synovial membrane. J Bone Joint Surg Am 78: 721-733.

Im GI, Jung NH, Tae SK (2006) Chondrogenic differentiation of mesenchymal stem cells isolated from patients in late adulthood: the optimal conditions of growth factors. Tissue Eng 12: 527-536.

Ivkovic A, Marijanovic I, Hudetz D, Porter RM, Pecina M, Evans CH (2011) Regenerative medicine and tissue engineering in orthopaedic surgery. Front Biosci 3: 923944.

Jin CZ, Cho JH, Choi BH, Wang LM, Kim MS, Park SR, Yun JH, Oh HJ, Min BH (2010) The maturity of tissueengineered cartilage in vitro affects the repairability for osteochondral defect. Tissue Eng Part A 17: 3057-3065.

Jones JI, Gockerman A, Busby WH, Jr., CamachoHubner C, Clemmons DR (1993) Extracellular matrix contains insulin-like growth factor binding protein-5: potentiation of the effects of IGF-I. J Cell Biol 121: 679687.

Kaul G, Cucchiarini M, Arntzen D, Zurakowski D, Menger MD, Kohn D, Trippel SB, Madry H (2006) Local 
stimulation of articular cartilage repair by transplantation of encapsulated chondrocytes overexpressing human fibroblast growth factor 2 (FGF-2) in vivo. J Gene Med 8: 100-111.

Khan IM, Gilbert SJ, Singhrao SK, Duance VC, Archer CW (2008) Cartilage integration: evaluation of the reasons for failure of integration during cartilage repair. A review. Eur Cell Mater 16: 26-39.

Kiernan JA (1999) Histological and histochemical methods - theory and practice. Butterworth-Heinemann, Oxford, UK. Chapter 5, pp 57-102.

Kupcsik L, Stoddart MJ, Li Z, Benneker LM, Alini M (2009) Improving chondrogenesis: potential and limitations of SOX9 gene transfer and mechanical stimulation for cartilage tissue engineering. Tissue Eng Part A 16: 1845-1855.

Langer R, Vacanti JP (1993) Tissue engineering. Science 260: 920-926.

Lefkoe TP, Trafton PG, Ehrlich MG, Walsh WR, Dennehy DT, Barrach HJ, Akelman E (1993) An experimental model of femoral condylar defect leading to osteoarthrosis. J Orthop Trauma 7: 458-467.

Loeser RF, Shanker G, Carlson CS, Gardin JF, Shelton BJ, Sonntag WE (2000) Reduction in the chondrocyte response to insulin-like growth factor 1 in aging and osteoarthritis: studies in a non-human primate model of naturally occurring disease. Arthritis Rheum 43: 21102120 .

Longobardi L, O'Rear L, Aakula S, Johnstone B, Shimer K, Chytil A, Horton WA, Moses HL, Spagnoli A (2006) Effect of IGF-I in the chondrogenesis of bone marrow mesenchymal stem cells in the presence or absence of TGF-beta signaling. J Bone Miner Res 21: 626-636.

Luyten FP, Hascall VC, Nissley SP, Morales TI, Reddi AH (1988) Insulin-like growth factors maintain steadystate metabolism of proteoglycans in bovine articular cartilage explants. Arch Biochem Biophys 267: 416-425.

Madry H, Cucchiarini M (2011) Clinical potential and challenges of using genetically modified cells for articular cartilage repair. Croat Med J 52: 245-261.

Madry H, Trippel SB (2000) Efficient lipid-mediated gene transfer to articular chondrocytes. Gene Ther 7: 286291.

Madry H, Zurakowski D, Trippel SB (2001) Overexpression of human insulin-like growth factor-I promotes new tissue formation in an ex vivo model of articular chondrocyte transplantation. Gene Ther 8: 1443 1449.

Madry H, Padera R, Seidel J, Langer R, Freed LE, Trippel SB, Vunjak-Novakovic G (2002) Gene transfer of a human insulin-like growth factor I cDNA enhances tissue engineering of cartilage. Hum Gene Ther 13: 1621-1630.

Madry H, Cucchiarini M, Stein U, Remberger K, Menger MD, Kohn D, Trippel SB (2003) Sustained transgene expression in cartilage defects in vivo after transplantation of articular chondrocytes modified by lipid-mediated gene transfer in a gel suspension delivery system. J Gene Med 5: 502-509.

Madry H, Kaul G, Cucchiarini M, Stein U, Zurakowski D, Remberger K, Menger MD, Kohn D, Trippel SB (2005) Enhanced repair of articular cartilage defects in vivo by transplanted chondrocytes overexpressing insulin-like growth factor I (IGF-I). Gene Ther 12: 1171-1179.

Madry H, Orth P, Cucchiarini M (2011a) Gene therapy for cartilage repair. Cartilage 2: 201-225.

Madry H, Orth P, Kaul G, Zurakowski D, Menger MD, Kohn D, Cucchiarini M (2011b) Acceleration of articular cartilage repair by combined gene transfer of human insulin-like growth factor I and fibroblast growth factor-2 in vivo. Arch Orthop Trauma Surg 130: 1311-1322.

Martel-Pelletier J, Di Battista JA, Lajeunesse D, Pelletier JP (1998) IGF/IGFBP axis in cartilage and bone in osteoarthritis pathogenesis. Inflamm Res 47: 90-100.

Martel-Pelletier J, Boileau C, Pelletier JP, Roughley PJ (2008) Cartilage in normal and osteoarthritis conditions. Best Pract Res Clin Rheumatol 22: 351-384.

Martin I, Miot S, Barbero A, Jakob M, Wendt D (2007) Osteochondral tissue engineering. J Biomech 40: 750-765.

Mauck RL, Nicoll SB, Seyhan SL, Ateshian GA, Hung CT (2003) Synergistic action of growth factors and dynamic loading for articular cartilage tissue engineering. Tissue Eng 9: 597-611.

Meinel L, Karageorgiou V, Hofmann S, Fajardo R, Snyder B, Li C, Zichner L, Langer R, Vunjak-Novakovic G, Kaplan DL (2004) Engineering bone-like tissue in vitro using human bone marrow stem cells and silk scaffolds. J Biomed Mater Res A 71: 25-34.

Middleton JF, Tyler JA (1992) Upregulation of insulinlike growth factor I gene expression in the lesions of osteoarthritic human articular cartilage. Ann Rheum Dis 51: 440-447.

Mikos AG, Herring SW, Ochareon P, Elisseeff J, Lu HH, Kandel R, Schoen FJ, Toner M, Mooney D, Atala A, Van Dyke ME, Kaplan D, Vunjak-Novakovic G (2006) Engineering complex tissues. Tissue Eng 12: 3307-3339.

Miot S, Scandiucci de Freitas P, Wirz D, Daniels AU, Sims TJ, Hollander AP, Mainil-Varlet P, Heberer M, Martin I (2006) Cartilage tissue engineering by expanded goat articular chondrocytes. J Orthop Res 24: 1078-1085.

Miot S, Brehm W, Dickinson S, Sims T, Wixmerten A, Longinotti C, Hollander AP, Mainil-Varlet P, Martin I (2012) Influence of in vitro maturation of engineered cartilage on the outcome of osteochondral repair in a goat model. Eur Cell Mater 23: 222-236.

Morales TI, Hascall VC (1989) Factors involved in the regulation of proteoglycan metabolism in articular cartilage. Arthritis Rheum 32: 1197-1201.

Mullen LM, Best SM, Brooks RA, Ghose S, Gwynne JH, Wardale J, Rushton N, Cameron RE (2010) Binding and release characteristics of insulin-like growth factor-1 from a collagen-glycosaminoglycan scaffold. Tissue Eng Part C Methods 16: 1439-1448.

Nixon AJ, Fortier LA, Williams J, Mohammed H (1999) Enhanced repair of extensive articular defects by insulinlike growth factor-I-laden fibrin composites. J Orthop Res 17: 475-487.

Nixon AJ, Brower-Toland BD, Bent SJ, Saxer RA, Wilke MJ, Robbins PD, Evans CH (2000) Insulin-like growth factor-I gene therapy applications for cartilage repair. Clin Orthop 43: S201-213.

Nixon AJ, Haupt JL, Frisbie DD, Morisset SS, McIlwraith CW, Robbins PD, Evans CH, Ghivizzani S 
(2005) Gene-mediated restoration of cartilage matrix by combination insulin-like growth factor-I/interleukin-1 receptor antagonist therapy. Gene Ther 12: 177-186.

Obradovic B, Martin I, Padera RF, Treppo S, Freed LE, Vunjak-Novakovic G (2001) Integration of engineered cartilage. J Orthop Res 19: 1089-1097.

Orth P, Kaul G, Cucchiarini M, Zurakowski D, Menger MD, Kohn D, Madry H (2011) Transplanted articular chondrocytes co-overexpressing IGF-I and FGF2 stimulate cartilage repair in vivo. Knee Surg Sports Traumatol Arthrosc 19: 2119-2130.

Orth P, Cucchiarini M, Kaul G, Ong MF, Graber S, Kohn DM, Madry H (2012a) Temporal and spatial migration pattern of the subchondral bone plate in a rabbit osteochondral defect model. Osteoarthritis Cartilage 20: 1161-1169.

Orth P, Zurakowski D, Wincheringer D, Madry H (2012b) Reliability, reproducibility, and validation of five major histological scoring systems for experimental articular cartilage repair in the rabbit model. Tissue Eng Part C Methods 18: 329-339.

Pei M, Seidel J, Vunjak-Novakovic G, Freed LE (2002) Growth factors for sequential cellular de- and redifferentiation in tissue engineering. Biochem Biophys Res Commun 294: 149-154.

Redman SN, Oldfield SF, Archer CW (2005) Current strategies for articular cartilage repair. Eur Cell Mater 9: 23-32.

Rogachefsky RA, Dean DD, Howell DS, Altman RD (1993) Treatment of canine osteoarthritis with insulin-like growth factor-1 (IGF-1) and sodium pentosan polysulfate. Osteoarthritis Cartilage 1: 105-114.

Safran MR, Seiber K (2010) The evidence for surgical repair of articular cartilage in the knee. J Am Acad Orthop Surg 18: 259-266.

Sah RL, Chen AC, Grodzinsky AJ, Trippel SB (1994) Differential effects of bFGF and IGF-I on matrix metabolism in calf and adult bovine cartilage explants. Arch Biochem Biophys 308: 137-147.

Saltzman WM (1999) Delivering tissue regeneration. Nat Biotechnol 17: 534-535.

Salzmann GM, Nuernberger B, Schmitz P, Anton M, Stoddart MJ, Grad S, Milz S, Tischer T, Vogt S, Gansbacher B, Imhoff AB, Alini M (2009) Physicobiochemical synergism through gene therapy and functional tissue engineering for in vitro chondrogenesis. Tissue Eng Part A 15: 2513-2524.

Schaefer D, Martin I, Jundt G, Seidel J, Heberer M, Grodzinsky A, Bergin I, Vunjak-Novakovic G, Freed LE (2002) Tissue-engineered composites for the repair of large osteochondral defects. Arthritis Rheum 46: 2524-2534.

Schinhan M, Gruber M, Vavken P, Dorotka R, Samouh L, Chiari C, Gruebl-Barabas R, Nehrer S (2012) Criticalsize defect induces unicompartmental osteoarthritis in a stable ovine knee. J Orthop Res 30: 214-220.

Sekiya I, Vuoristo JT, Larson BL, Prockop DJ (2002) In vitro cartilage formation by human adult stem cells from bone marrow stroma defines the sequence of cellular and molecular events during chondrogenesis. Proc Natl Acad Sci U S A 99: 4397-4402.
Sellers RS, Peluso D, Morris EA (1997) The effect of recombinant human bone morphogenetic protein-2 (rhBMP-2) on the healing of full-thickness defects of articular cartilage. J Bone Joint Surg Am 79: 1452-1463.

Sellers RS, Zhang R, Glasson SS, Kim HD, Peluso D, D'Augusta DA, Beckwith K, Morris EA (2000) Repair of articular cartilage defects one year after treatment with recombinant human bone morphogenetic protein-2 (rhBMP-2). J Bone Joint Surg Am 82: 151-160.

Shapiro F, Koide S, Glimcher MJ (1993) Cell origin and differentiation in the repair of full-thickness defects of articular cartilage. J Bone Joint Surg Am 75: 532-553.

Smith P, Shuler FD, Georgescu HI, Ghivizzani SC, Johnstone B, Niyibizi C, Robbins PD, Evans CH (2000) Genetic enhancement of matrix synthesis by articular chondrocytes: comparison of different growth factor genes in the presence and absence of interleukin-1. Arthritis Rheum 43: 1156-1164.

Solchaga LA, Yoo JU, Lundberg M, Dennis JE, Huibregtse BA, Goldberg VM, Caplan AI (2000) Hyaluronan-based polymers in the treatment of osteochondral defects. J Orthop Res 18: 773-780.

Stoddart MJ, Grad S, Eglin D, Alini M (2009) Cells and biomaterials in cartilage tissue engineering. Regen Med 4: 81-98.

Trippel SB, Corvol MT, Dumontier MF, Rappaport R, Hung HH, Mankin HJ (1989) Effect of somatomedin-C/ insulin-like growth factor I and growth hormone on cultured growth plate and articular chondrocytes. Pediatr Res 25: 76-82.

Uebersax L, Merkle HP, Meinel L (2008) Insulin-like growth factor I releasing silk fibroin scaffolds induce chondrogenic differentiation of human mesenchymal stem cells. J Control Release 127: 12-21.

van der Kraan PM, Buma P, van Kuppevelt T, van den Berg WB (2002) Interaction of chondrocytes, extracellular matrix and growth factors: relevance for articular cartilage tissue engineering. Osteoarthritis Cartilage 10: 631-637.

van Osch GJ, Brittberg M, Dennis JE, BastiaansenJenniskens YM, Erben RG, Konttinen YT, Luyten FP (2009) Cartilage repair: past and future - lessons for regenerative medicine. J Cell Mol Med 13: 792-810.

Wei X, Messner K (1999) Maturation-dependent durability of spontaneous cartilage repair in rabbit knee joint. J Biomed Mater Res 46: 539-548.

Weimer A, Madry H, Venkatesan JK, Schmitt G, Frisch J, Wezel A, Jung J, Kohn D, Terwilliger EF, Trippel SB, Cucchiarini M (2012) Benefits of rAAV-mediated IGF-I overexpression for the long-term reconstruction of human osteoarthritic cartilage by modulation of the IGF-I axis. Mol Med 18: 346-358.

Wolf F, Candrian C, Wendt D, Farhadi J, Heberer M, Martin I, Barbero A (2008) Cartilage tissue engineering using pre-aggregated human articular chondrocytes. Eur Cell Mater 16: 92-99.

Yoon DM, Fisher JP (2008) Effects of exogenous IGF-1 delivery on the early expression of IGF-1 signaling molecules by alginate embedded chondrocytes. Tissue Eng Part A 14: 1263-1273. 


\section{Discussion with Reviewers}

Reviewer I: There are still transfected cells detectable after 24 weeks. When do you expect that no transfected cells will be detectable in the tissue and is there a need to modify the lifetime of the transfected cells?

Authors: Longer studies are required to answer this important question. As the recombinant protein was only detected within the repair tissue, without intra-articular effects, we believe that there is no need to further expand the lifetime of the transfected and implanted chondrocytes.

Reviewer I: The authors correctly highlight that the described engineered cartilage model could not only help understanding the process of articular cartilage repair, but also possibly lead to a new treatment option for acute cartilage defects. In view of the latter consideration, which further steps would the authors envision to be necessary to move the approach towards a clinical translation?

Authors: The experimental foundation to generate cartilage by means of tissue engineering is well established, and its principle has already found entry into the surgical treatment of large symptomatic articular cartilage defects, as evidenced by the widespread use of matrix-induced autologous chondrocyte implantation (ACI), where the cells are attached to a biodegradable scaffold. Such supportive biomaterials may be similarly used to culture genetically modified human articular chondrocytes in bioreactors with the aim of a spatially controlled application of the modified chondrocytes in vivo. When delivered in a clinical setting, a construct that actively supports chondrogenesis would then fill the focal cartilage defect. In view of this consideration, further steps necessary to move this approach towards clinical translation include proofs of its safety in preclinical and clinical trials, the selection of the optimal therapeutic gene(s), the establishment of the optimal cell number per defect surface area needed for implantation and the choice of an appropriate gene vector system that allows for efficient gene transfer and controlled gene expression. Here, low-level, long-term transgene expression may be more appropriate compared to high-level, short-term gene expression as the repair tissue develops over a long period. Ex vivo nonviral gene transfer provides such characteristics and therefore holds clinical potential. During the bioreactor cultivation, the cartilaginous constructs may additionally be subjected to direct mechanical forces, allowing for an even more defined stimulation based on the interaction between growth- or transcription factors and dynamic loading.

Reviewer II: Preventive effects of the constructs on subsequent arthritis in adjacent cartilage are of great interest. The authors suggested a protective paracrine effect of the secreted IGF-1 on adjacent cartilage as a potential mechanism, but there are two conflicting results in the present study. In Figs. 3 and 4, immunohistochemistry demonstrated the prolonged expression of IGF-1 in the reparative tissues. However, the other data revealed that there was no significant difference in IGF-1 levels in the lavage fluids of the knees between IGF-1 and the lacZ group. The reviewer would like the authors to explain such discrepancy in IGF-1 expression in vivo.

Authors: Providing an IGF-I gene sequence via a tissue engineered construct allows for a spatially defined delivery of a therapeutic factor to articular cartilage defects, while simultaneously supplying a template filling the defect (Evans, 2011; Ivkovic et al., 2011). For example, when porous collagen-glycosaminoglycan scaffolds were loaded with IGF-I, a large part of the protein was released as a burst within the first day (Mullen et al., 2010). The positive immunoreactivity to IGF-I in the repair tissue of defects treated with both immature and mature IGF-I constructs, together with the positive immunoreactivity to $\beta$-gal in the repair tissue of defects treated with both immature and mature $l a c Z$ constructs, indicates prolonged expression of the transgene. This IGF-I produced by the chondrocytes within the tissue-engineered construct may have not only autocrine, but also paracrine effects on the mesenchymal cells (MSCs) from the subchondral bone marrow, as IGF-I can induce chondrogenesis in MSCs (Im et al., 2006; Longobardi et al., 2006; Uebersax et al., 2008). In contrast, IGF-I levels in the synovial fluid were normal, a desirable outcome for a clinical translation, where sideeffects of the therapeutic factor need to be avoided. Also, IGF-I overexpression did not result in adverse effects such as synovitis or infiltration of immune cells. These data are consistent with preceding reports (Brower-Toland et al., 2001; Madry et al., 2005; Madry et al., 2002; Smith et al., 2000) and correspond well to the normal IGF-I levels present already after day 4 post operation when 25,000 ng recombinant IGF-I ( $\sim$ 1,000-fold higher dose than the $\sim 2.2 \mathrm{ng}$ secreted by the constructs on day 2) were applied to osteochondral defects in a horse model (Fortier et al., 2002). Such normal IGF-I levels may result from the retention of the IGF-I within the repair tissue, for example by interaction with its binding proteins (Garcia et al., 2003; Sah et al., 1994; Weimer et al., 2012; Yoon and Fisher, 2008), increased binding to IGF-I receptors and extracellular matrix components, and/or elution of the protein.

Reviewer III: The defects were analysed after 24 weeks; do you expect that the transfected cells still produce IGF-I at this time point (if they are still alive)?

Authors: There was positive immunoreactivity to IGF-I in the repair tissue of defects treated with immature and mature IGF-I constructs, together with the positive immunoreactivity to $\beta$-gal in the repair tissue of defects that received lacZ constructs. Although IGF-I levels in the synovial fluid were not elevated, this suggests that at least some of the transfected, transplanted allogeneic chondrocytes continue to produce the growth factor within their new matrix. Transgene expression in cartilage defects has been previously shown to last for at least 36 weeks in vivo following implantation of allogeneic chondrocytes modified by adenoviral-mediated gene transfer in autogenous fibrin glue into $15 \mathrm{~mm}$ diameter osteochondral defects in an equine model (Hidaka et al., 2003). 